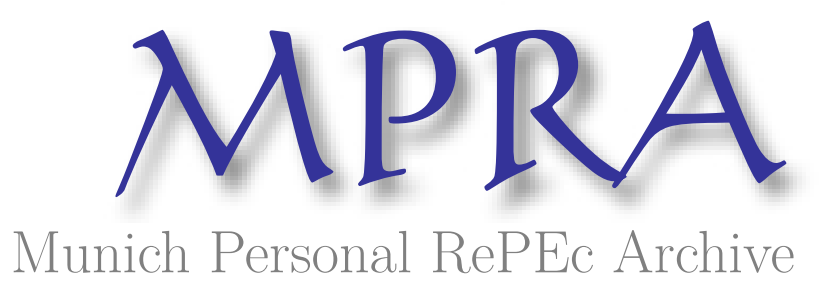

\title{
What do we know about the capital structure of privately held firms? Evidence from the Surveys of Small Business Finance
}

\author{
Cole, Rebel \\ DePaul University
}

16 March 2008

Online at https://mpra.ub.uni-muenchen.de/24669/

MPRA Paper No. 24669, posted 31 Aug 2010 04:19 UTC 


\title{
What Do We Know About the Capital Structure of Privately Held Firms? Evidence from the Surveys of Small Business Finance
}

\author{
Rebel A. Cole \\ DePaul University \\ Chicago, IL 60604 USA \\ rcole@depaul.edu
}

\begin{abstract}
:
Numerous studies have been conducted to test the two major competing theories of capital structure (Trade-Off Theory and Pecking-Order Theory), yet none of these studies has analyzed the capital-structure decisions of small, privately held U.S. firms, which constitute the vast majority of all U.S. business enterprises. In this study, we provide the first evidence on this important issue, utilizing data from four nationally representative surveys conducted by the Federal Reserve Board: the 1987, 1993, 1998 and 2003 Surveys of Small Business Finances (SSBF). We find that firm leverage as measured by the ratios of total loans to total assets and total liabilities to total assets is negatively related to firm size, age, profitability, liquidity and credit quality and is positively related to firm tangibility and limited liability. In addition, we find that firm leverage is an increasing function of both the number of banks and the number of non-bank financial institutions with which the firm has business relationships. Finally, we find no significant variations in firm leverage by race or ethnicity, but some evidence that femaleowned firms use less leverage. In general, these results are broadly supportive of the PeckingOrder Theory and inconsistent with the Trade-Off Theory.
\end{abstract}

Key words: capital structure, pecking-order theory, small business, trade-off theory, SSBF

JEL classification: G21, G32, L22, L26, M13 


\section{What Do We Know about the Capital Structure of Privately Held Firms? Evidence from the Surveys of Small Business Finance}

\section{Introduction}

According to many corporate finance textbooks, the capital structure decision is one of most fundamental issues facing financial managers. This seemingly simple decision as to the best mixture of capital sources to be employed in operating a firm has confounded researchers since the seminal work of Modigliani and Miller (1958). Existing empirical studies that test capital structure theories typically have relied upon data from large corporations with complex, publicly traded securities (see Frank and Goyal (2009) for a recent review). While such large, publicly traded corporations make up the bulk of business assets, they make up only a small fraction of the number of business entities. In the U.S., for example, there are only about 10,000 firms that issue publicly traded securities, yet, according to the U.S. Census, there are approximately 25 million business entities. These privately held firms are vital to the economy, producing as much as half of all job growth during the past decade. Therefore, a fundamental and unresolved issue in the finance literature is what factors determine the capital structure at privately held firms. In this study, we will provide important new evidence on this issue based upon data from a nationally representative survey of privately held firms.

In its simplest form, the capital-structure decision is the selection by firm management of a debt-to-equity ratio for the firm. ${ }^{1}$ For large, publicly traded firms, this decision is complicated along a number of different dimensions. Should the firm issue public debt or rely solely upon

\footnotetext{
${ }^{1}$ Each ratio of debt to equity maps uniquely to a ratio of debt to assets, a ratio of equity to assets and a ratio of assets to equity; however, corporate-finance textbooks tend to focus on the ratio of debt to equity when discussing capital structure. In this study, we focus on the ratio of debt to assets, as it does not take on negative values, whereas each of the other ratios is a function of equity, which often is negative for small privately held firms.
} 
private debt? Should the firm borrow in a domestic or a foreign currency from a domestic or foreign lender? Should the firm issue debt with or without convertibility features? One way to avoid these complications is to examine small privately held firms whose only capital-structure option is whether or not to borrow funds from a commercial bank or other financial intermediary. It is for these firms that the capital-structure decision most closely resembles the classic choice of a debt-to-equity ratio that is traditionally taught in the business-school classroom.

Using data from a nationally representative sample of privately held small businesses, this study contributes to the capital-structure literature in at least three important ways. First, we provide results from the first test of the two major competing hypotheses about capital structure based upon nationally representative data on privately held U.S. firms. ${ }^{2}$ This previously unaddressed segment of the market provides a new laboratory for reexamining the findings from prior studies that examine large, public-traded firms. Our focus on privately held firms enables us to eliminate the "noise" introduced by more complicated securities such as preferred stock and convertible bonds, reducing the errors-in-variable problems associated with empirical studies of capital structure at public firms. Also, as Myers (2000) points out, capital-structure "theories are not designed to be general" so that "testing them on a broad, heterogeneous sample of firms can be uninformative." By focusing on privately held firms, we tighten our focus to a more homogeneous sample: smaller firms with concentrated ownership structure that do not issue publicly traded securities.

In general, our results are broadly supportive of the Pecking-Order Theory over the Trade-Off Theory. We find a negative relation between firm leverage and firm size, age,

\footnotetext{
${ }^{2}$ Berger and Udell (1998) discuss the distribution of debt at small U.S. firms based upon 1993 data, but do not analyze determinant of capital structure.
} 
profitability and a positive relation between firm leverage and firm liquidity, risk and tangibility of assets.

Second, we provide new evidence on the degree of leverage used by privately held U.S. companies and how their use of leverage differs from that of small, publicly traded firms. We accomplish this by comparing data from our samples of privately held firms with data on small, publicly traded firms taken from the Compustat database. When compared with small, publicly traded firms, privately held firms exhibit similar leverage ratios, but this similarity does not hold up when we disaggregate by industry; this finding contradicts one of the key predictions of the Trade-Off Theory, which posits there are "target leverage ratios" that differ across industrial classification.

Third, we provide new evidence on how the use of financial institutions influences capital structure. We test whether firms that obtain financial services from a larger pool of financial institutions are able to employ more leverage. We find a positive and significant relation between firm leverage and the number of bank and non-bank financial institutions with which the firm has pre-existing relationships.

In Section 2, we review the literature on empirical tests of capital-structure theory. In Section 3, we describe our data. In Section 4, we present our hypotheses and describe our methodology. In Section 5, we present our results, followed by a summary and conclusions in Section 6. 


\section{Literature Review}

Almost fifty years have passed since the seminal work of Modigliani and Miller (1958 and 1963) on the importance of capital structure. Yet the seemingly simple question as to how firms should best finance their fixed assets remains a contentious issue. The empirical evidence regarding a firm's optimal mixture of financing during this time period is both voluminous and mixed in aggregate. ${ }^{3}$ Although there is no consensus, three competing theories-the Pecking Order Theory, the Trade-Off Theory, and the Market-Timing Theory-have emerged as the finance profession's best explanations for the capital-structure decision.

The Pecking-Order Theory (Myers and Majluf (1984), Myers (1984)) relies upon the concept of asymmetric information between managers and investors, which guides managers in their preference for raising funds. According to this theory, firms opt for funding from sources with the lowest degrees of asymmetric information because the cost of borrowing rises with this metric. Hence, firms opt first for internally generated funds (a form of "inside" equity), then for debt, and, only as a last result, for outside equity. Hence, a firm's capital structure is simply the result of previous independent decisions to raise capital; as a consequence, there is no "optimal" ratio of debt to equity under the Pecking-Order Theory (hereafter "POT").

Under the Trade-Off Theory of capital structure (hereafter "TOT"), the firm seeks to balance the tax benefits of using debt (which arise in the U.S. because interest payments are deductible business expenses while dividend payments are not) against costs of financial distress that rise at an increasing rate with the use of leverage. Hence, this theory predicts an "optimal" ratio of debt to equity, where the tax benefits of deductible interest are just offset by the costs of financial distress. For public firms, Graham (2000) estimates that the tax benefits of debt are

\footnotetext{
${ }^{3}$ Surveys of studies on capital structure include Bradley, Jarrell, and Kim (1984), Masulis (1988), Harris and Raviv (1991), Miller (1998), Myers (2001) and Frank and Goyal (2008). 
equal to almost 10 percent of a firm's market value. Given this idealized target, each financing decision by the firm is designed to move its capital structure towards this optimal ratio.

The Market-Timing Theory of capital structure (hereafter "MTT") is the most recent addition to the mix, emerging from a study by Baker and Wurgler (2002) that considers how the efforts of management to "time" the issuance of equity relate to the firm's capital structure. According to this theory, firms will raise capital by issuing equity in hot equity markets but by issuing debt in cold equity markets. The resulting capital structure of a firm is simply a function of when they needed to raise new capital. Those needing capital during hot equity market will have relatively low ratios of debt to equity while those needing capital during cold equity markets will have relatively high ratios of debt to equity. As with the POT, there is no "optimal" capital structure predicted by the MTT.

The ability to test whether or not an optimal capital structure exists for firms is complicated. The presence of an optimal mixture of capital can be difficult to isolate because firms operating with a target capital structure in mind will be hampered by adjustment and transaction costs. The continuous pricing of the firms' debt and equity in the marketplace will further complicate the issue. Moreover, the ability and speed of firms to adjust to deviations from their desired optimum structure also will vary. Recent studies by Leary and Roberts (2005), Flannery and Rangan (2006), Kahan and Titman (2006) and Lemmon, Roberts and Zender (2008) bear this out and indicate the persistence effects documented by the market-timing hypothesis of Baker and Wurgler are minor, and are more likely attributable to adjustment costs as firms seek to rebalance over time towards their targeted "optimal" capital structure.

Recent works by Shyam-Sunders and Myers (1999), Fama and French (2002), and Flannery and Rangan (2006) attempt to distinguish between the POT and TOT. As with so many 
previous studies on this topic, these researchers find conflicting evidence-some that supports and some that refutes each theory.

The inability to differentiate between the two theories beyond stylized facts is not altogether surprising, however, in light of the results from Graham and Harvey (2001), who conducted a survey of financial executives regarding a number of finance issues. More than eighty percent of the respondents indicated that a "target" ratio or range of ratios guided their decision-making with respect to capital structure-evidence in favor of the TOT. Yet the same survey also found that managers prefer to first use retained earnings for financing new projects and maintain financial flexibility, with a debt reserve for potential future projects-evidence in favor of the POT.

Titman and Wessels (1988) and Graham and Harvey (2001) both indicate that differences in the utilization of debt may exist between large and small firms as a result of transaction costs. Since Booth et al. (2001) and Desai, Foley, and Hines (2004) find evidence of persistent differences in capital structure across countries, we should also expect further noise to be found with larger multinational firms accessing capital in different marketplaces. The novelty of using data from privately held firms to address the capital-structure decision is that these firms are devoid of many of the noise-inducing complications that afflict publicly traded firms.

Frank and Goyal (2008) provide a summary of the existing literature on tests of the Trade-off and Pecking-Order theories of capital structure. They report that "there is a core set of seven reliable factors that are correlated with cross-sectional differences in leverage. Leverage is positively related to median industry leverage, collateral, log of assets, and expected inflation. Leverage is negatively related to market-to-book, profits, and a dummy variable for a firm paying dividends." 
To summarize, there are three major competing theories - the Pecking Order Theory, the Trade-Off Theory, and the Market-Timing Theory_-that have emerged as the finance profession's best explanations for the capital-structure decision. However, only the first two of these three theories are relevant for privately held firms that do not issue publicly traded securities, which, by itself, is strong evidence against the Market-Timing theory. In the remainder of this paper, we test whether the POT or the TOT better explain the capital structure of privately held U.S. companies.

\section{Data}

To conduct this study, we utilize data from four independent, cross-sectional surveys of privately held U.S. firms conducted for the U.S. Federal Reserve Board and U.S. Small Business Administration: the 1987, 1993, 1998, and 2003 Surveys of Small Business Finance (“SSBF”). In each survey, the firms surveyed constitute a nationally representative sample of "small businesses" operating in the U.S. as of year-end 1987/1993/1998/2003, where a "small business" is defined as a non-financial, non-farm enterprise employing fewer than 500 full-time equivalent employees. The survey data are broadly representative of approximately five million firms operating in the U.S. as of each survey year. In each survey, there are a very small number of firms that indicated they were publicly traded. We exclude these firms so that our samples contain only privately held firms. ${ }^{5}$

\footnotetext{
4 See Wolken and Elliehausen (1988), Cole and Wolken (1995), Bitler, Robb and Wolken (2001) and Mach and Wolken (2006) for detailed descriptions of the 1987, 1993, 1998 and 2003 surveys, respectively.

${ }^{5}$ We exclude 15 (32, 10 and 9) publicly traded firms from the 1987 (1993, 1998 and 2003) SSBFs, respectively, so that we have a clean test of publicly traded versus privately held firms.
} 
The SSBF provides detailed information about each firm's balance sheet and income statement; its credit history and use of financial services and institutions; the firm's characteristics, including standard industrial classification (SIC), organizational form (proprietorship, partnership, LLP, LLC, S-corporation or C-corporation), and age; and demographic characteristics of each firm's primary owner, including race, ethnicity and gender. With the exception of the 1987 survey, the SSBFs also provide information on the primary owner's age, education, experience, and credit history. Balance-sheet and income-statement data are derived from the enterprise's year-end financial statements. Credit history, firm characteristics, and demographic characteristics of each firm's primary owner are taken as of year-end. Each survey variable used in this study is defined in Table 1.

We utilize two alternative measures of capital structure in this study: the ratio of total loans to total assets, and the ratio of total liabilities to total assets. The ratio of total liabilities to total assets maps one-to-one with the ratio of debt-to-equity; hence, it corresponds to the traditional measure of leverage that is the focus of most textbook discussions of capital structure. However, total liabilities include current liabilities, which may be viewed as essential to doing business and, therefore, outside of the manager's capital-structure decision. Therefore, we also analyze the ratio of total loans to total assets, which, for our firms, is, essentially, total liabilities less current liabilities, divided by total assets. In practice, both measures are highly correlated in each of the four SSBFs so that the results obtained using each measure are quite similar. ${ }^{6}$

\footnotetext{
${ }^{6}$ Welch (2010) critiques three common flaws in empirical capital structure research, one of which is the use of the debt-to-asset ratio as a measure of leverage. He writes "The financial debt-to-asset ratio is flawed as a measure of leverage because the converse of financial debt is not equity. This is because most of the opposite of the financial debt-to-asset ratio is the nonfinancial liabilities-to-asset ratio. This problem is easy to remedy-researchers should use a debt-to-capital ratio or a liabilities-to-asset ratio." He goes on to say that flawed measures of leverage may be acceptable if they are highly correlated with correct measures. The correlations
} 
Frank and Goyal (2008) enumerate four major problems faced by empirical researchers doing cross-sectional studies of capital structure: how to define leverage (market versus book), how to treat panel data, how to deal with missing values and how to deal with outliers. Because we are analyzing privately held firms, we have only book values of debt and equity; market values do not exist for these firms. Also, we do not have panel data, so we do not have to worry about panel-data issues, such as lack of independence across observations. With respect to missing values, we are fortunate that Federal Reserve Board staff already has imputed missing values; we rely upon their expert and well-documented efforts. With respect to outliers, we have chosen to winsorize problematic variables, which include each of our financial ratios. This involves replacing values outside of some percentile (typically, the 95th or 99th) with the value at that percentile.

We also utilize annual financial data on publicly traded firms from Compustat, extracting data from 1987, 1993, 1998 and 2003. ${ }^{7}$ For comparison purposes, we calculate median leverage ratios in each year. For purposes of testing the TOT, we calculate median leverage ratios by year and by one- and two-digit standard industrial classifications, which we use as proxies for "target leverage ratios" predicted by the TOT.

of the two leverage measures used in this study are greater than 0.80 , which presumably is "high enough."

${ }^{7}$ We select all active firms in each year with total assets (DATA6) greater than zero and employment (DATA29) greater than zero. For consistency with the SSBF, we delete firms in two-digit SIC codes less than 10, in codes 43, 60, 61, 62, 63, 67 and 86 and in codes greater than 89. (These firms were excluded from the SSBF.) We calculate the ratio of liabilities to assets as total liabilities (DATA181) divided by total assets (DATA6). We calculate the ratio of loans to assets as the sum of long-term debt (DATA9) and short-term debt (DATA34) divided by total assets (DATA6). We calculate the ratio of tangible assets to total assets as gross property, plant and equipment (DATA7) divided by total assets (DATA6). 


\section{Hypotheses and key explanatory variables}

According to the TOT, a firm balances the benefits from the tax deductibility of interest, which are substantial, ${ }^{8}$ against the costs of financial distress. The firm takes on additional debt until the marginal benefit of the tax shield provided by the deductibility of interest expense is equal to the marginal costs imposed by the increased probability of financial distress that accompanies higher leverage. The TOT leads to several testable hypotheses. Factors that are associated with higher probabilities of financial distress should be associated with lower leverage. Factors that are associated with greater tax benefits from the deductibility of interest expense should be associated with higher leverage.

According to the POT, asymmetric information leads the firm to a "pecking order" in its search for funding, first using internally generated funds (primarily retained earnings), then tapping private debt (primarily in the form of loans from financial institutions), and seeking equity from outside sources only as a last resort. ${ }^{9}$ For small, privately held firms, outside equity is rarely available, so the fundamental choice is between insiders' equity and private debt. ${ }^{10}$ The POT also leads to several testable hypotheses. Financial slack can be used to fund projects when external equity is unavailable or prohibitively expensive so a firm with more financial slack should use less leverage. Tangible assets can be used as loan collateral so a firm with more tangible assets should use more leverage. To the extent that tangible assets are measured with

\footnotetext{
${ }^{8}$ Graham (2000) estimates that tax benefits of debt are worth approximately ten percent of the market value of a firm.

${ }^{9}$ Public firms typically do not use dividend policy to adjust capital structure because dividend cuts are severely punished in equity markets. It is not clear if the "stickiness" of dividends also applies to small privately held firms.

${ }^{10}$ Later versions of the SSBF include a section where firms are queried about their ability to obtain outside equity. In the 2003 SSBF, only 68 out of 4,240 firms indicated that they were able to obtain outside equity during the 12 months prior to the survey.
} 
error but also are correlated with industry classification, a firm in an industry with a higher

portion of tangible assets should use more leverage. More profitable firms generate more internal fund so a more profitable firm should use less leverage.

In the following discussion, we limit our focus to privately held firms that choose their capital structure primarily by raising funds from insiders' equity or outside private debt (primarily bank loans).

\subsection{Firm Size}

Firm size influences the probability of financial distress. Larger firms are more diversified and have been shown to have lower probabilities of default. Therefore, if the TOT is correct, then we should observe a positive relation between firm size and leverage.

Typically, there is much more information available in the marketplace about larger firms than about smaller firms, so informational asymmetries between insiders and outsiders will be less severe at larger firms. Therefore, the POT predicts that larger firms should use proportionately more debt than smaller firms, also implying a positive relation between firm size and leverage.

Measuring the size of privately held firms is problematic. Typically, three alternative variables are used in the finance and entrepreneurship literatures to measure the size of such firms: total assets, annual sales revenues and total employment. Total assets is probably the most common measure of firm size, but, in our samples, this variable presents problems with respect to both missing values and outliers. First, a small portion of the firms did not report total assets to SSBF interviewers, forcing FRB staff to impute these values. Second, many firms that did report total assets reported values that appear inconsistent with other measures of size. This is 
especially problematic for very small firms in the service industries that have few assets, yet generate significant sales revenues and employ many workers. Sales revenues present similar but less severe problems. Some firms report zero, or very small values of, sales revenues.

Total employment presents the fewest problems in both of these respects. All firms reported employment, as this was a sampling criterion, and outliers are uncommon because firm size was limited to 500 or fewer employees. However, the surveys had to deal with how to classify firms reporting zero employees-firms whose owners did all of the work. The early surveys replaced zero values with one-half of an employee, assuming that the owner worked at least part time. The 2003 survey finally recognized that zero employee firms are not unusual, and that owners are not "employees" as defined by employment law.

Because each of these size measures suffers problems, we test all three measures as proxies for firm size, but focus on total assets, as this is the measure most commonly used in the literature and is highly correlated with the other two measures.

\subsection{Firm Age}

Younger firms need capital to finance growth. Younger firms also are typically less creditworthy, less profitable and less diversified than older firms, so they have higher probabilities of financial distress. Therefore, the TOT predicts that younger firms should use less leverage, implying a positive relation between firm age and leverage.

Younger firms have less of a track record than older firms, having had less time to establish a reputation, so that informational asymmetry between insiders and outsiders should be more severe at younger firms. According to the POT, such firms should prefer internal equity to private debt, implying a positive relation between firm age and leverage. However, younger 
firms have had less time to generate retained earnings and build up financial slack. According to the POT, such firms should prefer private debt because they don't have access to internally generated firms. Hence, the net prediction of the POT regarding the relation between firm age and leverage is ambiguous.

We include the natural logarithm of firm age to perform this test. We use the log transformation because we expect that a one year difference in age is more important to the leverage of a young firm than to the leverage of an old firm.

\subsection{Profitability}

Firm profitability strongly influences the probability of financial distress. The more profitable is the firm, the less likely is the firm to default on its liabilities. In addition, the more profitable is the firm, the more taxes it can avoid by employing higher leverage. For both reasons, the TOT predicts a positive relation between firm profitability and leverage.

The more profitable is the firm, the greater is the availability of internally generated funds. Therefore, the POT predicts a negative relation between firm profitability and leverage. In a study of firms from five developed countries, Wald (1999) finds that profitability is the single most important determinant of leverage, as measured by the ratio of debt to assets.

The SSBFs provide information on the net income of the firm, which enables us to construct the most common measure of profitability—return on assets (ROA), which is defined as net income divided by total assets. However, SSBF data on profitability is noisy, with a significant portion of the observations requiring imputation. Therefore, as a robustness test, we also construct a zero-one indicator variable for profitable firms, i.e., those firms reporting profits greater than zero. This is a much simpler and cleaner measure of profitability than ROA. 


\subsection{Liquid Assets}

The expected costs of financial distress will be lower for firms with a higher portion of their assets invested in cash, and cash-equivalent, assets. Therefore, the TOT predicts that leverage will be higher for firms with more liquid assets.

In contrast, the POT posits that firms value "financial slack" in the form of liquid assets. Financial slack enables firms to take advantage of unexpected investment opportunities without having to raise new outside capital from either the debt or equity markets. Therefore, the POT predicts a negative relation between liquid assets and firm leverage. We measure liquid assets using the ratio of cash and cash equivalents to total assets.

\subsection{Tangible Assets}

The expected costs of financial distress will be negatively related to the portion of a firm's assets that are tangible, as these assets suffer smaller percentage losses in liquidation and can be pledged as collateral to obtain preferential financing. If the TOT is correct, then we should observe a positive relation between the ratio of tangible assets to total assets and firm leverage.

Harris and Raviv (1991) argue that the problem of asymmetric information is smaller when a firm has more tangible assets that can readily be valued. Therefore, the POT also predicts that firms with more tangible assets should be able to utilize more debt, as lenders can look to the tangible assets as collateral without regard to asymmetric information. This implies that firms in industries that typically rely upon tangible assets should have higher leverage ratios than firms in industries that rely upon intangible assets. Long and Malitz (1985) find that leverage ratios are 
inversely related to the amount of the firm's intangible assets (proxied for by R\&D

development). Schwartz and Aronson (1967) provide evidence of strong industry effects in debt ratios.

Researchers typically measure tangible assets using the ratio of fixed assets (plant, property and equipment) to total assets, but some researchers also include inventory in the ratio's numerator. We test both proxies for tangible assets.

As a robustness test, we use COMPUSTAT data to calculate the industry median ratio of tangible assets to total assets by two-digit SIC code and use that as a proxy for each SSBF firm's tangible-asset ratio.

\subsection{Growth Prospects}

The expected costs of financial distress are greater for a firm with better growth opportunities because the value of these opportunities is an intangible asset (although not necessarily a book value), and much of the value of these growth opportunities is lost in financial distress because they cannot be funded and realized. If the TOT is correct, then we should observe a negative relation between proxies for growth opportunities and firm leverage.

Growth opportunities are notoriously difficult to value, but especially so by observers outside the firm, so that asymmetric information should be more severe when a firm has more growth opportunities. Hence, the POT also predicts that firms with better growth prospects would rely upon inside equity instead of private debt.

To measure growth opportunities, we rely upon a proxy created from information on current and prior-period employment. We construct two dummy variables-one for firms reporting an increase in the number of employees and one for firms reporting a decrease in 
employment. The omitted category, which typically accounts for a majority of firms, is firms reporting no change in the number of employees. This fact renders the actual change in employment a very noisy measure because of the large mass point at zero. Unfortunately, the 1998 SSBF did not collect information on prior period employment so we cannot perform this test for that survey.

As a robustness test, we also construct proxies for growth opportunities based upon current and prior-period sales. The 2003 SSBF did not collect information on the value of priorperiod sales, only whether sales revenues had increased, decreased or remained the same since the prior period. Therefore, we again rely upon dummy variables for positive or negative sales growth.

\subsection{Creditworthiness}

Firms that are more creditworthy have lower probabilities of financial distress. According to the TOT, such firms should use more leverage, so the TOT predicts a positive relationship between measures of credit quality and firm leverage. The POT says nothing about the creditworthiness of the firm, so it makes no predictions regarding the relation between credit quality and leverage.

The SSBFs include several variables that provide information about the creditworthiness of the firm: the number of business delinquencies during the past three years, the number of personal delinquencies of the primary owner during the past three years, whether the firm and/or primary owner has declared bankruptcy within the past seven years, whether any judgments had been rendered against the primary owner during the past three years, whether the firm has ever been denied trade credit and whether the firm has paid late on its trade credit. However, only 
one of these variables is available across all four surveys-whether or not the firm has made late payments on its trade credit. Consequently, we use this as our primary measure of credit quality. We use the other variables as measures of robustness.

Each of these survey variables indicates firms of lower credit quality; consequently, we expect that, if the TOT is correct, each of these variables should have a negative relation with measures of leverage. A positive relation would be inconsistent with the TOT, yet consistent with the POT.

\subsection{Industry Leverage}

The TOT posits that firms target an "optimal" leverage ratio. According to Frank and Goyal (2004), the industry-median leverage ratio is a likely proxy for firms to use as their target. If the industry median is a good proxy for this target, and the TOT is correct, then we should observe a positive relation between the industry median leverage ratio and individual firm leverage ratios.

To the extent that asymmetric information is related to unobservable factors that are correlated within industry, as seems likely, the POT at least suggests a positive relation between the industry-median leverage ratio and firm leverage.

In order to perform this test, we calculate median industry leverage ratios using data from Compustat firms with fewer than 500 employees; we then use these industry medians as a proxies for the "target" leverage ratios. 
Below is a summary of the key predictions regarding the POT and the TOT.

\section{Variables used to Explain Capital Structure at Privately Held Firms: Expected Signs Under Alternative Theories}

Variable
Firm Size
Firm Age
Profitability
Liquid Assets
Tangible Assets
Growth Prospects
Creditworthiness
Industry "target" leverage ratios

\section{Methodology}

In order to provide new evidence on the determinants of capital structure at small firms, we employ both univariate and multivariate techniques. First, we calculate and analyze descriptive statistics (primarily the means and medians) for alternative measures of capital structure by selected firm and owner characteristics. Second, we estimate a weighted-leastsquares regression model of the form:

$$
\begin{aligned}
& \text { Leverage }=\mathrm{f}(\text { size }, \text { age }, \text { profitability, liquidity, tangible assets, } \\
& \text { growth opportunities, credit quality, control variables })
\end{aligned}
$$

For control variables, we include information on the ethnicity, gender and race of the firm's primary owner. Several studies in the literature (e.g., Blanchflower, Levine and Zimmerman (2003); Cavalluzzo and Cavalluzo (1998)) provide evidence that minority-owned firms are more likely to be denied credit by lenders than non-minority firms. If such firms are consistently denied credit based upon non-financial factors, then we should observe lower 
leverage ratios at such firms. We include dummy variables for Asian-, Black-, Female- and Hispanic-controlled firms to test this proposition.

We also include variables that measure the number of financial institutions from which the firm obtains financial services. The relationship literature has established that firms having pre-existing relationships with financial institutions are more likely to be granted credit than other firms (Cole (1998); Cole, Goldberg and White (2004); Chakravarty and Yilmazer (2004)). Therefore, the more financial institutions with which a firm has relationships, the more credit it should be able to obtain and the higher its leverage ratio should be. However, other researchers hypothesize that lenders want exclusive relationships with their borrowers so that they can extract monopoly rents. If this is the case, then firms with more relationships should be able to obtain less credit than other firms and, consequently, have lower leverage ratios.

We use two variables to measure the number of financial institutions: the number of commercial banks, and the number of financial institutions other than commercial banks, from which the firm obtains financial services. Non-bank financial institutions typically are finance companies, leasing companies or thrift institutions.

\section{Results}

\subsection{Univariate Results}

In Tables $2 \mathrm{~A}$ and $2 \mathrm{~B}$, we present descriptive statistics for our analysis variables across each of the four SSBFs. Table 2A shows the medians while Table $2 \mathrm{~B}$ shows the means from each of the four SSBFs for each variable. More complete descriptive statistics (number of observations, median, mean, standard error, minimum and maximum) appear in Appendix Tables 1A-D. 
Median leverage varied from a low of $7.5 \%$ in 2003 to a high of $25.0 \%$ in 1993 when measured by total loans to total assets, and from a low of $27.5 \%$ in 2003 to a high of $47.4 \%$ in 1993 when measured by total liabilities to total assets. It is not surprising that the highest leverage ratios were observed during the "credit crunch" that was ongoing in 1993.

For comparison, we calculate the median leverage ratios for all Compustat firms and for Compustat firms with fewer than 500 employees (Table 3). These comparisons give us an idea of how similar or different are the leverage ratios of public and privately held companies. For all public firms, the loan-to-asset ratio (shown in Panel A) ranges from 21.1\% in 1998 and 2003 to 25.5\% in 1987, and the liabilities-to-asset ratio (shown in Panel B) ranges from 37.9\% in 1998 to $56.5 \%$ in 1987. For the small public firms, the loan-to-asset ratios range from $11.3 \%$ in 2003 to $20.1 \%$ in 1987 , and the liabilities-to-asset ratios range from $43.5 \%$ in 1998 to $56.5 \%$ in 2003 . Hence, it appears that privately held firms employ a comparable degree of leverage relative to publicly traded firms of similar size when leverage is measured by the ratio of loans to assets, but employ less leverage when leverage is measured by the ratio of total liabilities to total assets. This is quite surprising, as public firms have gained access to new equity from the public markets, so one would expect them to use less leverage than comparable privately held firms.

It is important to note, however, that the median number of employees for these "small" Compustat firms ranges from 99 to 132, while the median number of employees for the SSBF firms ranges from 3 to 4 . As this comparison makes clear, even the smallest of publicly-traded firms are orders of magnitudes larger than the typical privately held firm.

The median size for the SSBF firms ranges between $\$ 58,113$ and $\$ 99,000$ in terms of total assets, between $\$ 160,000$ and $\$ 250,000$ in terms of annual sales revenues and, as previously noted, between 3 and 4 in terms of total employment. In general, firm size declined from 1987 to 
1993 and 1998, but rose from 1998 to 2003. In real dollar terms, these declines in assets and sales would be even larger, as these are nominal values.

Median firm age increased from 10 years in 1987 to 12 years in 2003. Profitability, as measured by ROA, varied from $20.71 \%$ in 1987 to $33.60 \%$ in 1998 . Liquidity, as measured by the ratio of cash to total assets, ranged from $8.47 \%$ in 1987 to a high of $11.7 \%$ in 1998 . Tangible assets, as measured by the ratio of inventory plus plant, property and equipment to total assets, ranged from $54.5 \%$ in 2003 to $70.0 \%$ in 1993.

For the remainder of the variables, which are zero-one indicator variables, the medians are all zero, with the exception of the numbers of financial institutions from which the firm obtained financial services. The median number of commercial banks was one for each of the four surveys, while the median number of non-banks was zero for 1987 and one for the remaining three surveys.

As shown in Table 2B, the averages for firm leverage, size, profitability and liquidity are much larger than the corresponding medians-evidence of the substantial skewness in these distributions. Average leverage rose in each survey year, from $31.2 \%$ in 1987 and $61.4 \%$ in 2003 when measured by total loans to total assets; and from $48.7 \%$ in 1987 to $84.8 \%$ in 2003 when measured by total liabilities to total assets. The average size ranges from $\$ 425,000$ to $\$ 568,000$ as measured by total assets, from $\$ 1.00$ million to $\$ 1.25$ million as measured by annual sales and from 8.5 to 11.1 as measured by total employment. Average profitability varied from $55.7 \%$ in 1987 to $87.3 \%$ in 1998 . Average liquidity was between $16.2 \%$ in 1987 and $24.3 \%$ in $1998 .^{11}$

\footnotetext{
${ }^{11}$ In each survey, we winsorize financial ratios to mitigate the effect of large outliers in the data. Both measures of leverage are winsorized at the $95 \%$ percentiles, while both ROA and the ratio of cash to assets are winsorized at the $99 \%$ percentiles.
} 
Average tangible assets ranged from 51.3\% in 2003 to $65.6 \%$ in 1993. Credit quality, as measured by the percentage of firms paying late on their trade credit accounts, improved from 1987 to 2003 , declining from $42.0 \%$ to $24.7 \%$ of all firms.

The average number of commercial banks from which a firm obtained financial services declined from 1.317 in 1987 to 1.246 in 2003, while the number of nonbanks rose from 0.725 to 1.165. The total number of financial institutions used (both bank and nonbank) rose from 2.042 in 1987 to 2.411 in 2003, indicating that the increase in use of nonbanks more than offset the decline in the use of commercial banks.

The period from 1987-2003 saw dramatic changes in organizational form, as the percentage of firms organized as C-corporations declined from $39.2 \%$ to $14.6 \%$, while the percentage organized as S-corporations rose from $12.4 \%$ to $31.4 \%$. The percentage of partnerships remained relatively constant at $8 \%-9 \%$, while the percentage of proprietorships rose slightly from $40 \%$ to $44 \%$. The 1998 and 2003 surveys also provide information on firms organized as limited-liability corporations, which was $0.8 \%$ in 1998 and $1.4 \%$ in 2003. (In this table, limited-liability partnerships are aggregated with regular partnerships.)

There also were dramatic changes from 1987 to 2003 in the distribution of small firms by gender, race and ethnicity. The percentage of female-owned firms increased from $13.8 \%$ to 25.8\%; the percentage of Asian-owned firms grew from $3.0 \%$ to $4.5 \%$; the percentage of Blackowned firms grew from $2.3 \%$ to $3.8 \%$; and the percentage of Hispanic-owned firms grew from $2.0 \%$ to $4.3 \% .^{12}$

We also see significant changes in the distribution of firms by industry over the 19872003 period. Firms in Retail Trade (SIC 52-59) and Wholesale Trade (SIC 50-51) declined from

\footnotetext{
${ }^{12}$ In this table, owners who are Black and Hispanic are included only in the Black category so that the statistics for Hispanics are biased downwards slightly.
} 
$26.4 \%$ to $18.6 \%$ and from $10.0 \%$ to $6.0 \%$, respectively, while firms in Business Services (SIC 70-79) and Professional Services (SIC $80-89$ ) rose from $18.4 \%$ to $24.9 \%$, and from $13.2 \%$ to $20.7 \%$, respectively.

In Tables 4A and 4B, we present median leverage ratios broken out by selected firm and owner characteristics. In Table 4A are the medians for the ratio of total loans to total assets. For the full SSBF samples, median loan-to-asset ratios were $17.7 \%$ in 1987, 25.1\% in 1993, 9.2\% in 1998 and $7.4 \%$ in 2003. Panel A of Table 4A breaks down the sample firms by organizational form and shows that Proprietorships use far less leverage than do any of the organizational forms that enjoy limited liability. This is not surprising, as proprietors are personally liable for the liabilities of their firms, whereas the owners of corporations and partnerships (except for the general partner) are not. The median proprietorship used no loans in 1998 and 2003, but borrowed 19.6\% of assets in 1993, during the height of the 1990s "credit crunch." S-corporations used the greatest percentage of loans in every year (28.4\% in 1987, 35.2\% in 1993 and $25.7 \%$ in 1998) except for 2003, when C-corporations were most highly levered at $26.1 \%$. Partnership leverage was comparable to corporate leverage in 1987 and 1993, and fell between corporate leverage and proprietorship leverage in 1998 and 2003.

Panel B of Table 4A breaks down the sample into asset quartiles. In 1987, 1998 and 2003, we see a monotonic relation between size and leverage, with larger firms using more leverage. In each of these years, the median firm in the smallest quartile used no leverage, while the median firm in the largest quartile borrowed loans equal to $20.6 \%-27.3 \%$ of assets. During the credit crunch survey year of 1993, this relation was reversed, with the largest firms using the least leverage and smaller firms using the most leverage. 
Panel $\mathrm{C}$ of Table 4A breaks survey samples down by firm age: 0-5, 6-10, 11-20 and 21 plus years old. These correspond roughly, but not exactly, to age quartiles. In each survey, we see a negative monotonic relation between firm age and leverage. The oldest firms report the lowest ratios of loans to assets, while the youngest firms report the highest ratios of loans to assets. There is one exception, in 1998, when the youngest firms reported less leverage than any group except for the 21-plus year-old firms. As with other breakdowns, leverage ratios are uniformly higher in 1993 than other years.

Panel D of Table 4A breaks down the samples by race: Asian, Black, White Hispanic, White Non-Hispanic, and Other. In general, minority-owned firms report lower median leverage ratios than White Non-Hispanic firms. Panel E of Table 3A breaks down the samples by gender. Female-owned firms use less leverage than male firms in each year, but these differences are greatest in 1998 and 2003, when female firms used virtually no loans while male firms used loans equal to 11 percent of assets.

In Table 4B are the medians for the ratio of total liabilities to total assets. For the full SSBF samples, median liability-to-asset ratios were $39.4 \%$ in $1987,47.4 \%$ in $1993,34.7 \%$ in 1998 and $27.5 \%$ in 2003 . The results by organizational form, asset size, firm age and race, ethnicity and gender are qualitatively similar to those reported in Table 4A.

\subsection{Multivariate Results}

In Tables 5A and 5B, we present the results of weighted-least-squares regression analysis where the dependent variable is either the ratio of total loans to total assets (Table 5A) or the ratio of total liabilities to total assets (Table 5B). Each observation is weighted by its survey sampling weight, which is the inverse of its selection probability for that sample. This weighting 
enables us to use our results to make inferences about the target population, rather than the survey sample.

In Table 5A are the results for leverage as measured by the ratio of total loans to total assets, where the upper tail of the distribution has been winsorized at the 99th percentile. With respect to firm characteristics, the results are remarkably consistent across the four surveys. For many of these variables, the signs are consistent and the coefficients are statistically significant at better than the 0.05 level across each of the four surveys.

Firm size, as measured by the natural logarithm of total assets, is inversely related to firm leverage, and this relation is significant at better than the 0.001 level in each survey. In other words, larger firms use significantly less debt in their capital structure. This result is at odds with what Frank and Goyal (2006, p. 64) cite as one of the "core set of seven factors that are correlated with cross-sectional differences in leverage." Cross-sectional studies of publiclytraded firms find that leverage is "robustly related" to firm size, as measured by the log of assets. Clearly, this result does not hold for privately held firms. This result also is inconsistent with the TOT, which predicts larger firms should use more leverage than smaller firms. The POT is ambiguous with respect to the effect of firm size on leverage.

Firm age, as measured by the natural logarithm of firm age, also is inversely related to firm leverage. In each of the four surveys, the relation is significant at better than the 0.001 level. Older firms use less debt in their capital structure. This result is inconsistent with the TOT, which predicts that older firms should be more highly levered than their younger counterparts. The POT is ambiguous with respect to the effect of firm age on leverage.

Profitability, as measured by the winsorized return on assets, shows a consistent negative relation with the loan-to-asset ratio. The coefficients for ROA are significant at the 0.05 level for 
three of the four surveys, with 1998 being the exception. As a robustness test (not shown in Table 5), we replace ROA with a simple zero-one indicator for profitable firms. We find that this variable has a negative and highly significant coefficient in each of the four surveys. These latter findings are strongly supportive of the POT, which predicts that profitable firms use less debt because they can fund projects with retained earnings, but is inconsistent with the TOT, which predicts that profitable firms use more debt to take advantage of the debt tax shield, and because they have lower probability of financial distress.

Liquidity, as measure by the winsorized ratio of cash to total assets, is inversely related to firm leverage in each of the four surveys, and this relation is statistically significant at better than the 0.01 level in each survey, except for 2003, where it is significant at the 0.05 level. The coefficient ranges from -0.199 to -0.347 , indicating that a 100 basis point increase in the ratio of cash to assets reduces the ratio of debt to assets by 20 to 35 basis points. This result is supportive of the POT, which predicts that firms with more liquid assets have financial slack that can be used in place of new debt to fund unexpected investment opportunities; and is inconsistent with the TOT, which predicts that firms with more liquid assets have a lower probability of financial distress and should use more leverage.

Tangibility, as measured by the ratio of property, plant and equipment to total assets, is positive across each of the four surveys and is statistically significant at better than the 0.05 level for each survey excepting 2003. The coefficients range from 0.073 to 0.171 , indicating that a 100 basis point increase in the tangible asset ratio is associated with a 7.3 to17.1 basis point increase in the loan-to-asset ratio. According to Frank and Goyal (2006, p. 39), the relation between tangibility and leverage is reliably positive in cross-sectional studies of publicly traded firms. Our results for privately held firms are broadly consistent with this finding. 
Creditworthiness, as measured by Trade Credit Paid Late, is positively related to firm leverage. Firms indicating that they made late payments on their trade credit accounts have consistently higher ratios of debt to assets than other firms. The coefficient on this variable is significant at the 0.001 level for three of the four surveys, with 1993 being the exception. The coefficient ranges from 0.008 to 0.268 , indicating that the debt-to-asset ratios were 0.8 to 26.8 percentage points higher for such firms. Similar results are obtained for firms reporting that they were delinquent on their business obligation, but this variable is not available from the 1987 survey. In general, these results are inconsistent with the TOT because these firms have higher probabilities of financial distress. Because the POT says nothing about creditworthiness, the results do not contradict the POT.

Target leverage ratios, as proxied by the Compustat median-industry leverage ratios, are not significantly different from zero in any of the four surveys (not shown in Table 5). This is inconsistent with the TOT and with evidence from cross-sectional studies of leverage at publicly traded corporations. Frank and Goyal (2006, p. 41) report that median industry leverage is one of the "core set of seven reliable factors that are correlated with cross-sectional differences leverage."

Moving on to the relationship variables, we find that the debt-to-asset ratio is positively related to both the number of commercial banks and to the number of non-banks from which the firm obtains financial services. These results are statistically significant at better than the 0.001 level in each of the four surveys. The coefficients range from 0.049 to 0.216 , indicating that a firm could increase its debt-to-asset ratio by 4.9 to 21.6 percentage points by establishing a new relationship with one new financial institution. In general, the results are stronger for relationships with financial institutions other than commercial banks. 
With respect to organizational form, the coefficients on both S-corporations and C-corporations are positive and significant at better than the 0.01 level in each period. These variables show the additional leverage used by corporations relative to the omitted categoryproprietorships. The coefficients indicate that corporations have debt to asset ratios that are 3.5 to 48.1 percentage points higher than proprietorships. These results are consistent with the findings regarding organizational form shown in Table 2A. The coefficients on partnerships are positive in each period, and significant in each period except for 1993, indicating that partnerships also use more leverage than proprietorships but less than corporations. These findings are consistent with the limited liability protection offered by the differing organizational forms—none for proprietorships, limited for partnerships and full for corporations. Results for LLCs are only available from the 1998 and 2003 surveys. The coefficient is large, positive and significant in 1998, but slightly negative and insignificant in 2003 . These results are due to small sample sizes and large variation among LLCs.

Results for race and ethnicity of the firm's primary owner are generally insignificant. Only the 1993 coefficient for Black-owned firms is statistically significant at better than the 0.05 level. By gender, both the 1993 and 2003 coefficients for female owned firms are negative and significant. The result for 2003 is highly significant with a t-statistic of 5.08 and a coefficient of -0.289 , indicating that female-owned firms had loan-to-asset ratios that were 28.9 percentage points lower than those for male-owned firms. By industry, there are no consistent results, although several individual coefficients are significant in each year.

Table 5B presents WLS regression results where leverage is measured by the winsorized ratio of total liabilities to total assets. In general, the results are qualitatively similar to those in Table 5A. This is not surprising, as the correlation coefficients for our two measures of leverage 
are greater than 0.80 in each of the four surveys. One notable exception is profitability, as measured by winsorized return on assets. The coefficient on ROA is negative and significant in 1987, negative and insignificant in 1993 and 2003, but positive and significant in 1998. However, when we replace ROA with a simple zero-one indicator variable for profitable firms, we find a positive and highly significant relation between profitability and leverage in each of the four surveys. This is supportive of the POT and inconsistent with the TOT.

\subsection{Robustness Tests of Multivariate Results}

Not shown in the tables are results where we replace the natural logarithm of total assets with the natural logarithm of annual sales revenue and the natural logarithm of total employment. In both cases, the results are essentially unchanged, although the adjusted $\mathrm{R}^{2}$ falls by more than half. These results confirm that leverage is inversely related to firm size, even when size is measured by sales or employment rather than assets. They also confirm that results for other variables are independent of our measure of firm size.

We also replace our measure of firm age (natural logarithm of firm age) with a series of zero-one indicator variables for firms age 0-5, 6-10, 11-20 and 21-plus. In this specification, only the dummy variable for the youngest firms aged zero to five years is statistically significant. The coefficient is positive and in the range of 0.20 , indicating that young firms have leverage ratios that are 20 percentage points higher than older firms.

For each survey, except for 1987, we replace the dummy variable for Trade Credit Paid Late with a dummy variable indicating that the firm was at least 60 days delinquent upon a business obligation at some time during the past three years. Like Trade Credit Paid Late, this 
variable for Delinquent Business Obligation is positive and significant at better than the 0.001 level in each period, indicating that firms with lower quality use more leverage.

We include dummy variables indicating whether the firm does business primarily locally, regionally, nationally, or internationally. In1987, 1993 and 2003, we find that firms doing business primarily nationally, or primarily internationally, have significantly higher leverage ratios than other businesses. The variables are not significant in the 1998 survey.

We include a dummy variable indicating that the firm's primary owner used her personal credit card(s) for business purposes. In each of the three surveys for which this measure is available, we find that such firms have significantly higher leverage ratios than firms whose primary owned does not use personal credit card(s) for business purposes. (This variable is not available in the $1987 \mathrm{SSBF})$.

Finally, we rerun our analyses limiting our sample to corporations (S-corporations, Ccorporations and LLCs) because our analysis in Tables 4 and 5 indicate highly significant differences in the leverage of proprietorships and corporations. Our results using the ratio of total loans to total assets appear in Table 6, Panel A, and our results using the ratio of total liabilities to total assets appear in Table 6, Panel B. Surprisingly, our results for both measures of leverage are, in general, not qualitatively different from those appearing in Table 5, Panels A and B. 


\section{Summary and Conclusions}

The capital-structure decision is one of the most fundamental issues in corporate finance. Numerous studies have been conducted to test the two major competing theories of capital structure - the Trade-Off Theory and the Pecking-Order Theory-yet none of these studies has analyzed the capital-structure decisions of privately held U.S. firms, which constitute the vast majority of all U.S. business enterprises. In this study, we provide the first evidence on this important issue, utilizing data from four nationally representative surveys conducted by the Federal Reserve Board: the 1987, 1993, 1998 and 2003 Surveys of Small Business Finances (SSBF).

Our results show that firm leverage, as measured by the ratios of total loans to total assets and total liabilities to total assets, is negatively related to firm size, age, profitability, liquidity and credit quality, and is positively related to firm tangibility and limited liability. In addition, we find that firm leverage is an increasing function of both the number of banks and the number of non-bank financial institutions with which the firm has business relationships. Finally, we find no significant variations in firm leverage by race or ethnicity, but some evidence that female-owned firms use less leverage. In general, these results are broadly supportive of the Pecking-Order Theory and inconsistent with the Trade-Off Theory.

Our results contribute to the literature on capital structure and relationship lending in at least four important ways. First, we provide results from the first test of the major competing hypotheses about capital structure based upon data from privately held U.S. firms. Previous research has relied upon data from publicly traded corporations, where the capital-structure decision is complicated by the wide variety of debt and equity instruments used by large firms. Second, we provide new evidence on the degree of leverage used by privately held companies 
and how their use of leverage differs from small publicly traded firms. This is important to any assessment of how economic shocks may affect privately held firms. Third, we provide new evidence on how the use of financial institutions influences capital structure. Fourth, we pool data from four different surveys collected over 15 years that span at least two business cycles, which enables us to provide new evidence on how macro-economic conditions influence the capital-structure decision of privately held firms. 


\section{REFERENCES}

Ang, J., Cole, R., Lin, J. (2000). Agency costs and ownership structure. The Journal of Finance $55,81-106$

Baker, M., Wurgler, J. (2002). Market timing and capital structure. The Journal of Finance 57, $1-32$.

Berger, A., Udell, G. (1998). The economics of small business finance: The roles of private equity and debt markets in the financial growth cycle. Journal of Banking \& Finance 22, 613673.

Bitler, M., Robb, A., Wolken, J. (2001). Financial Services Used by Small Businesses: Evidence from the 1998 Survey of Small Business Finances. Federal Reserve Bulletin, 87, 183-205.

Brealey, R., Myers, S., and Allen, F. (2006). Principles of Corporate Finance. McGraw HillIrwin (New York, NY).

Blanchflower, D., Levine, P., Zimmerman, D. (2003). Discrimination in the small business credit market. Review of Economics and Statistics 85, 930-43.

Cavalluzzo, K., Cavalluzzo, L. (1998). Market structure and discrimination: The case of small businesses. Journal of Money, Credit, and Banking 30, 771-792.

Chakravarty, S., Yilmazer, T. (2009). A multi-stage model of loans and the role of relationships. Purdue University working paper. Financial Management.

Cole, R. (1998). The importance of relationships to the availability of credit. Journal of Banking \& Finance 22, 959-997.

Cole, R., Goldberg, L., White, L. (2004). Cookie-cutter versus character: The micro-structure of small-business lending by large and small banks. Journal of Financial and Quantitative Analysis 39, 227-251.

Cole, R., Wolken, J. (1995). Financial services used by small businesses: Evidence from the 1993 National Survey of Small Business Finances. Federal Reserve Bulletin, vol. 81 (July), pp. 630-67.

DeAngelo, H., Masulis, R. (1980). Optimal capital structure under corporate and personal taxation. Journal of Financial Economics 8, 3-29.

Donaldson, G. (1961). Corporate debt capacity: a study of corporate debt policy and the determination of corporate debt capacity. Harvard Business School, Division of Research, Harvard University. 
Elliehausen, G., Wolken, J. (1990). Banking markets and the use of financial services by small and medium-sized businesses. Federal Reserve Bulletin, Vol. 76 (October), pp. 801-817.

Fama, E., French, K. (1997). Industry costs of equity. Journal of Financial Economics 43, 153193.

Fama, E., French, K. (2002). Testing trade-off and pecking order predictions about dividends and debt. Review of Financial Studies 15, 1-34.

Faulkender, M., Petersen, M., (2006). Does the source of capital affect capital structure? Review of Financial Studies, 19, 45-79.

Fischer, E., Heinkel, R., Zechner, J. (1989). Dynamic capital structure choice: theory and tests. Journal of Finance 44, 19-40.

Flannery, M., Rangan, K. (2006). Partial adjustments toward target capital structures. Journal of Financial Economics 79, 469-506.

Frank, M., Goyal, V. (2003). Testing the pecking order theory of capital structure. Journal of Financial Economics 67, 217-248.

Frank, M., Goyal, V. (2009). Capital structure decisions: which factors are reliably important? Financial Management, 1-37.

Frank, M., Goyal, V. (2008). Tradeoff and pecking-order theories of debt. In E. Eckbo (Ed.), The Handbook of Empirical Corporate Finance. North-Holland).

Graham, J. (2000). How big are the tax benefits of debt? The Journal of Finance 55, 1901-1941

Graham, J., Harvey, C. (2001). The theory and practice of corporate finance: evidence from the field. Journal of Financial Economics 60, 187-243.

Greene, W. (2003). Econometric Analysis, 5th Ed. Upper Saddle River, Prentice Hall.

Halov, N., Heider, F. (2004). Capital structure, risk and asymmetric information. NYU Working Paper.

Hovakimian, A. (2006). Are observed capital structures determined by equity market timing? Journal of Financial and Quantitative Analysis 41, 221-243.

Hovakimian, A., Opler, T., Titman, S. (2001). The debt-equity choice: An analysis of issuing firms. Journal of Financial and Quantitative Analysis 36, 1-24.

Hovakimian, A., Hovakimian, G., Tehranian, H. (2004). Determinants of target capital structure: the case of dual debt and equity issues. Journal of Financial Economics 71, 517-540. 
Huang, R., Ritter, J. (2005). Testing the market timing theory of capital structure. University of Florida Working paper.

Jalilvand, A., Harris, R. (1984). Corporate behaviour in adjusting to capital structure and dividend targets: an econometric study. The Journal of Finance 39, 127-145.

Ju, N., Parino, R., Poteshman, A., Weisbach, M. (2002). Horses and rabbits? Optimal dynamic capital structure from shareholder and manager perspectives. NBER Working paper 9327.

Kayhan, A., Titman, S. (2007). Firms' histories and their capital structures. Journal of Financial Economics 83, 1-32.

Korajczyk, R., Levy, A. (2003). Capital structure choice: macroeconomic conditions and financial constraints. Journal of Financial Economics 68, 75-109.

Leary, M., Roberts, M. (2005). Do firms rebalance their capital structure? The Journal of Finance 60, 2575-2619.

Leland, H. (1998). Agency costs, risk management, and capital structure, The Journal of Finance $53,1213-1244$.

Lemmon, M., Zender, J. (2004). Debt capacity and tests of capital structure theories. University of Utah and University of Colorado Working Paper.

Lemmon, M., Roberts, M., Zender, J. 2008. Back to the beginning: Persistence and the crosssection of corporate capital structure. The Journal of Finance 63, 1575-1608.

Mach, T., Wolken, J. (2006). Financial services used by small businesses: Evidence from the 2003 Survey of Small Business Finances. Federal Reserve Bulletin. Vol. 92 (October) 167-194.

Marsh, P. (1982). The choice between equity and debt: an empirical study. The Journal of Finance 37, 121-144.

Mauer, D., Triantis, A. (1994). Interactions of corporate financing and investment decisions: a dynamic framework. The Journal of Finance 49, 1253-1277.

Modigliani, F., Miller, M. (1958). The cost of capital, corporation finance, and the theory of investment. American Economic Review 48, 655-669.

Myers, S. (1984). The capital structure puzzle. The Journal of Finance 39, 575-592.

Myers, S. (2001). Capital structure. Journal of Economic Perspectives 15, 81-102.

Myers, S., Majluf, N. (1984). Corporate financing and investment decisions when firms have information that investors do not have. Journal of Financial Economics 13, 187-221. 
Rajan, R., Zingales, L. (1995). What do we know about capital structure: some evidence from international data. The Journal of Finance 50, 1421-1460.

Roberts, M. (2002). The dynamics of capital structure: an empirical analysis of a partially observable system. Duke University Working Paper.

Ross., S., Westerfield, R., Jaffe, J. (2004). Corporate Finance. $7^{\text {th }}$ Edition. McGraw-Hill Irwin (New York, NY).

Shyam-Sunder, L., Myers, S. (1999). Testing static tradeoff against pecking order models of capital structure. Journal of Financial Economics 51, 219-243.

Titman, S., Tsyplakov, S. (2004). A dynamic model of optimal capital structure. University of Texas Working Paper.

Welch, I. (2004). Capital structure and stock returns. Journal of Political Economy 112, 106-131.

Welch, I. 2010. A bad measure of leverage: The financial-debt-to-asset ratio (April 18, 2010). AFA 2008 New Orleans Meetings Paper. Available at http://ssrn.com/abstract=931675. 
Table 1

\section{Definitions of Variables Used to Explain Capital Structure}

(Data are taken from the 1987, 1993, 1998 and 2003 Surveys of Small Business Finances)

\section{Variable}

Firm Characteristics

Leverage ratio 1

Leverage ratio 2

Assets

Sales

Employment

Firm Age

ROA

Liquid Assets

Tangible Assets

Growth Prospects

Firm Delinquent on Business

Obligation

Trade Credit Paid Late

Number of Banks

Number of Nonbanks

Number of Fin'l Institutions

C-Corporation

S-Corporation

LLC

Partnership

Proprietorship

Owner's Race, Ethnicity and Gender

Female Owner

Asian Owner

Black Owner

Hispanic Owner

Industrial Classification

SIC 1

SIC 2

SIC 3

SIC 4

SIC 51

SIC 52

SIC 6

SIC 7

SIC 8

Total loans divided by total assets

Total liabilities divided by total assets

Total assets

Annual sales revenues

Total full-time equivalent employment

Age of the firm in years

Net income divided by total assets

Cash divided by total assets

Sum of inventory and property, plant and equipment divided by total assets

Dummy variables for firms with positive and negative Employment growth during previous three years. (No growth is omitted category.)

Firm has been $60+$ days delinquent on a business obligation during previous three years

During the year, the firm has made payments on a trade credit account after the bill was due in full.

Number of commercial banks from which the firm obtains financial services.

Number of financial institutions other than commercial banks from which the firm obtains financial services.

Number of financial institutions including commercial banks from which the firm obtains financial services.

Firm files taxes as a C-corporation.

Firm files taxes as an S-corporation.

Firm files taxes as a Limited Liability Corporation.

Firm files taxes as a Partnership or Limited Liability Partnership.

Firm files taxes as a Proprietor

At least $51 \%$ of the firm is owned by a female.

At least $51 \%$ of the firm is owned by an Asian.

At least $51 \%$ of the firm is owned by a Black.

At least $51 \%$ of the firm is owned by an Hispanic.

Firm is in SIC 10-19: Mining and Construction

Firm is in SIC 20-29: Primary Manufacturing

Firm is in SIC 30-39: Secondary Manufacturing

Firm is in SIC 40-49: Transportation, Communication and Utilities

Firm is in SIC 50-51: Wholesale Trade

Firm is in SIC 52-59: Retail Trade

Firm is in SIC 64-67: Insurance and Real Estate (other financial service firms were excluded from the SSBF).

Firm is in SIC 70-79: Business Services

Firm is in SIC 80-89: Professional Services 
Table 2

Descriptive Statistics for Variables Used to Explain Capital Structure

Panel A: Variable Medians

(Data are taken from the 1987, 1993, 1998 and 2003 Surveys of Small Business Finances)

\begin{tabular}{|c|c|c|c|c|}
\hline Variable & $\begin{array}{c}1987 \\
\text { Median }\end{array}$ & $\begin{array}{c}1993 \\
\text { Median }\end{array}$ & $\begin{array}{c}1998 \\
\text { Median }\end{array}$ & $\begin{array}{c}2003 \\
\text { Median }\end{array}$ \\
\hline \multicolumn{5}{|l|}{ Firm Characteristics } \\
\hline Loans to Assets & 0.177 & 0.251 & 0.092 & 0.074 \\
\hline Liabilities to Assets & 0.394 & 0.474 & 0.347 & 0.275 \\
\hline Total Assets & 99,000 & 69,435 & 58,113 & 72,000 \\
\hline Sales & 250,000 & 190,000 & 160,000 & 200,000 \\
\hline Employment & 4 & 3 & 3 & 3 \\
\hline Firm Age & 10 & 11 & 11 & 12 \\
\hline ROA & 0.2071 & 0.213 & 0.336 & 0.287 \\
\hline Cash to Total Assets & 0.0847 & 0.108 & 0.117 & 0.105 \\
\hline Tangible Assets to Total Assets & 0.6667 & 0.700 & 0.558 & 0.545 \\
\hline Employment Growth is Positive & 0 & 0 & 0 & 0 \\
\hline Employment Growth in Negative & 0 & 0 & 0 & 0 \\
\hline Firm Delinquent on Business Obligation & $\mathrm{n} / \mathrm{a}$ & 0 & 0 & 0 \\
\hline Trade Credit Paid Late & 0 & 0 & 0 & 0 \\
\hline Number of Banks & 1 & 1 & 1 & 1 \\
\hline Number of Nonbanks & 0 & 1 & 1 & 1 \\
\hline Number of Fin'l Institutions & 2 & 2 & 2 & 2 \\
\hline C-Corporation & 0 & 0 & 0 & 0 \\
\hline S-Corporation & 0 & 0 & 0 & 0 \\
\hline LLC & N/A & N/A & 0 & 0 \\
\hline Partnership & 0 & 0 & 0 & 0 \\
\hline Proprietorship & 0 & 0 & 0 & 0 \\
\hline \multicolumn{5}{|l|}{ Owner's Race, Ethnicity and Gender } \\
\hline Female Owner & 0 & 0 & 0 & 0 \\
\hline Asian Owner & 0 & 0 & 0 & 0 \\
\hline Black Owner & 0 & 0 & 0 & 0 \\
\hline Hispanic Owner & 0 & 0 & 0 & 0 \\
\hline \multicolumn{5}{|l|}{ Industrial Classification } \\
\hline SIC 1 & 0 & 0 & 0 & 0 \\
\hline SIC 2 & 0 & 0 & 0 & 0 \\
\hline SIC 3 & 0 & 0 & 0 & 0 \\
\hline SIC 4 & 0 & 0 & 0 & 0 \\
\hline SIC 51 & 0 & 0 & 0 & 0 \\
\hline SIC 52 & 0 & 0 & 0 & 0 \\
\hline SIC 6 & 0 & 0 & 0 & 0 \\
\hline SIC 7 & 0 & 0 & 0 & 0 \\
\hline SIC 8 & 0 & 0 & 0 & 0 \\
\hline
\end{tabular}


Table 2

Descriptive Statistics for Variables Used to Explain Capital Structure

Panel B: Variable Means

(Data are taken from the 1987, 1993, 1998 and 2003 Surveys of Small Business Finances)

\begin{tabular}{|c|c|c|c|c|}
\hline Variable & $\begin{array}{c}1987 \\
\text { Mean }\end{array}$ & $\begin{array}{c}1993 \\
\text { Mean }\end{array}$ & $\begin{array}{c}1998 \\
\text { Mean }\end{array}$ & $\begin{array}{c}2003 \\
\text { Mean }\end{array}$ \\
\hline \multicolumn{5}{|l|}{ Firm Characteristics } \\
\hline Loans to Assets & 0.312 & 0.354 & 0.399 & 0.614 \\
\hline Liabilities Assets & 0.487 & 0.561 & 0.756 & 0.849 \\
\hline Total Assets & 476,254 & 488,844 & 424,989 & 567,881 \\
\hline Sales & $1,251,382$ & $1,001,330$ & $1,005,846$ & $1,098,386$ \\
\hline Employment & 11.145 & 8.494 & 8.715 & 8.736 \\
\hline Firm Age & 13.265 & 14.284 & 13.392 & 14.381 \\
\hline ROA & 0.557 & 0.690 & 0.873 & 0.749 \\
\hline Cash to Total Assets & 0.162 & 0.197 & 0.243 & 0.225 \\
\hline Tangible Assets to Total Assets & 0.6150 & 0.656 & 0.520 & 0.513 \\
\hline Employment Growth is Positive & 0.2421 & 0.377 & $\mathrm{n} / \mathrm{a}$ & 0.154 \\
\hline Employment Growth is Negative & 0.1247 & 0.268 & $\mathrm{n} / \mathrm{a}$ & 0.077 \\
\hline Firm Delinquent on Business Obligation & N/A & 0.190 & 0.136 & 0.159 \\
\hline Trade Credit Paid Late & 0.420 & 0.363 & 0.270 & 0.247 \\
\hline Number of Banks & 1.317 & 1.262 & 1.226 & 1.246 \\
\hline Number of Nonbanks & 0.725 & 0.844 & 0.839 & 1.165 \\
\hline Number of Fin'l Institutions & 2.042 & 2.106 & 2.065 & 2.411 \\
\hline C-Corporation & 0.392 & 0.284 & 0.193 & 0.146 \\
\hline S-Corporation & 0.124 & 0.203 & 0.243 & 0.314 \\
\hline LLC & N/A & N/A & 0.008 & 0.014 \\
\hline Partnership & 0.081 & 0.080 & 0.068 & 0.086 \\
\hline Proprietorship & 0.403 & 0.432 & 0.488 & 0.440 \\
\hline \multicolumn{5}{|l|}{ Owner's Race, Ethnicity and Gender } \\
\hline Female Owner & 0.138 & 0.206 & 0.238 & 0.258 \\
\hline Asian Owner & 0.030 & 0.036 & 0.043 & 0.045 \\
\hline Black Owner & 0.023 & 0.029 & 0.040 & 0.038 \\
\hline Hispanic Owner & 0.020 & 0.043 & 0.056 & 0.043 \\
\hline \multicolumn{5}{|l|}{ Industrial Classification } \\
\hline SIC 1 & 0.131 & 0.142 & 0.119 & 0.116 \\
\hline SIC 2 & 0.042 & 0.039 & 0.038 & 0.031 \\
\hline SIC 3 & 0.048 & 0.042 & 0.047 & 0.041 \\
\hline SIC 4 & 0.029 & 0.028 & 0.037 & 0.039 \\
\hline SIC 51 & 0.100 & 0.085 & 0.072 & 0.060 \\
\hline SIC 52 & 0.264 & 0.217 & 0.192 & 0.186 \\
\hline SIC 6 & 0.068 & 0.071 & 0.064 & 0.070 \\
\hline SIC 7 & 0.184 & 0.211 & 0.246 & 0.249 \\
\hline SIC 8 & 0.132 & 0.166 & 0.183 & 0.207 \\
\hline
\end{tabular}


Table 3:

Panel A

Median Ratios of Total Loans to Total Assets by One-Digit Standard Industrial Classification

Compustat vs. SSBF

For each year, the first column presents the median ratio for all Compustat firms, the second column presents the median ratios for Compustat firms with fewer than 500 employees and the third column presents the weighted median ratio for all SSBF firms. R

\begin{tabular}{|c|c|c|c|c|c|c|c|c|c|c|c|c|}
\hline \multirow[b]{2}{*}{ SIC Industry } & \multicolumn{3}{|c|}{2003} & \multicolumn{3}{|c|}{1998} & \multicolumn{3}{|c|}{1993} & \multicolumn{3}{|c|}{1987} \\
\hline & Compustat & $\begin{array}{l}\text { Compustat } \\
<500 \text { Emp }\end{array}$ & SSBF & Compustat & $\begin{array}{l}\text { Compustat } \\
<500 \text { Emp }\end{array}$ & SSBF & Compustat & $\begin{array}{l}\text { Compustat } \\
<500 \text { Emp }\end{array}$ & SSBF & Compustat & $\begin{array}{l}\text { Compustat } \\
<500 \text { Emp }\end{array}$ & SSBF \\
\hline 1 Construction & 0.234 & 0.168 & 0.087 & 0.276 & 0.222 & 0.133 & 0.192 & 0.133 & 0.199 & 0.215 & 0.158 & 0.128 \\
\hline 2 Primary Manufacturing & 0.214 & 0.096 & 0.207 & 0.208 & 0.073 & 0.122 & 0.166 & 0.089 & 0.317 & 0.216 & 0.106 & 0.183 \\
\hline 3 Secondary Manufacturing & 0.163 & 0.073 & 0.108 & 0.185 & 0.083 & 0.161 & 0.170 & 0.104 & 0.225 & 0.209 & 0.190 & 0.233 \\
\hline 4 Transportation & 0.341 & 0.296 & 0.280 & 0.357 & 0.315 & 0.320 & 0.348 & 0.341 & 0.348 & 0.360 & 0.342 & 0.215 \\
\hline 5.1 Wholesale Trade & 0.239 & 0.220 & 0.091 & 0.256 & 0.135 & 0.160 & 0.277 & 0.238 & 0.200 & 0.286 & 0.300 & 0.189 \\
\hline 5.2 Retail Trade & 0.189 & 0.203 & 0.141 & 0.218 & 0.224 & 0.102 & 0.202 & 0.227 & 0.276 & 0.255 & 0.217 & 0.192 \\
\hline 6 Financial Services & 0.216 & 0.258 & 0.060 & 0.303 & 0.277 & 0.209 & 0.192 & 0.258 & 0.366 & 0.300 & 0.428 & 0.293 \\
\hline 7 Business Services & 0.114 & 0.073 & 0.030 & 0.111 & 0.069 & 0.017 & 0.119 & 0.064 & 0.245 & 0.185 & 0.194 & 0.215 \\
\hline 8 Professional Services & 0.184 & 0.153 & 0.00 & 0.201 & 0.145 & 0.027 & 0.238 & 0.204 & 0.243 & 0.238 & 0.154 & 0.082 \\
\hline All Firms & 0.211 & 0.113 & 0.075 & 0.222 & 0.114 & 0.092 & 0.211 & 0.133 & 0.250 & 0.255 & 0.201 & 0.177 \\
\hline
\end{tabular}


Table 3:

Panel B

Median Ratios of Total Liabilities to Total Assets by One-Digit Standard Industrial Classification

Compustat vs. SSBF

For each year, the first column presents the median ratio for all Compustat firms, the second column presents the median ratios for Compustat firms with fewer than 500 employees and the third column presents the weighted median ratio for all SSBF firms. $\mathrm{R}$

\begin{tabular}{|c|c|c|c|c|c|c|c|c|c|c|c|c|}
\hline \multirow[b]{2}{*}{ SIC Industry } & \multicolumn{3}{|c|}{2003} & \multicolumn{3}{|c|}{1998} & \multicolumn{3}{|c|}{1993} & \multicolumn{3}{|c|}{1987} \\
\hline & Compustat & $\begin{array}{l}\text { Compustat } \\
<500 \text { Emp }\end{array}$ & SSBF & Compustat & $\begin{array}{l}\text { Compustat } \\
<500 \text { Emp }\end{array}$ & SSBF & Compustat & $\begin{array}{l}\text { Compustat } \\
<500 \text { Emp }\end{array}$ & SSBF & Compustat & $\begin{array}{l}\text { Compustat } \\
<500 \text { Emp }\end{array}$ & SSBF \\
\hline 1 Construction & 0.515 & 0.461 & 0.325 & 0.522 & 0.450 & 0.421 & 0.475 & 0.357 & 0.488 & 0.539 & 0.414 & 0.372 \\
\hline 2 Primary Manufacturing & 0.521 & 0.341 & 0.357 & 0.505 & 0.302 & 0.468 & 0.477 & 0.297 & 0.554 & 0.510 & 0.347 & 0.363 \\
\hline 3 Secondary Manufacturing & 0.469 & 0.377 & 0.371 & 0.463 & 0.356 & 0.409 & 0.465 & 0.379 & 0.491 & 0.491 & 0.424 & 0.432 \\
\hline 4 Transportation & 0.689 & 0.652 & 0.363 & 0.661 & 0.649 & 0.619 & 0.648 & 0.624 & 0.622 & 0.625 & 0.603 & 0.313 \\
\hline 5.1 Wholesale Trade & 0.608 & 0.598 & 0.416 & 0.556 & 0.469 & 0.450 & 0.610 & 0.612 & 0.531 & 0.590 & 0.514 & 0.489 \\
\hline 5.2 Retail Trade & 0.503 & 0.566 & 0.343 & 0.520 & 0.514 & 0.357 & 0.480 & 0.452 & 0.458 & 0.549 & 0.491 & 0.410 \\
\hline 6 Financial Services & 0.635 & 0.640 & 0.240 & 0.625 & 0.621 & 0.378 & 0.578 & 0.579 & 0.500 & 0.625 & 0.641 & 0.517 \\
\hline 7 Business Services & 0.529 & 0.534 & 0.200 & 0.486 & 0.436 & 0.246 & 0.471 & 0.454 & 0.463 & 0.498 & 0.471 & 0.430 \\
\hline 8 Professional Services & 0.555 & 0.542 & 0.185 & 0.557 & 0.555 & 0.238 & 0.527 & 0.399 & 0.430 & 0.571 & 0.461 & 0.208 \\
\hline All Firms & 0.447 & 0.565 & 0.275 & 0.379 & 0.435 & 0.347 & 0.538 & 0.484 & 0.474 & 0.565 & 0.476 & 0.394 \\
\hline
\end{tabular}


Table 4

Median Capital Structure Ratios by Selected Firm and Owner Characteristics Panel A: Capital Structure as Measured by the Ratio of Total Loans to Total Assets

(Data are taken from the 1987, 1993, 1998 and 2003 Surveys of Small Business Finances)

\begin{tabular}{|c|c|c|c|c|c|c|c|c|}
\hline Variable & $\begin{array}{l}1987 \\
\text { Obs }\end{array}$ & $\begin{array}{l}\text { SSBF } \\
\text { Median }\end{array}$ & $\begin{array}{l}1993 \\
\text { Obs }\end{array}$ & $\begin{array}{l}\text { SSBF } \\
\text { Median }\end{array}$ & $\begin{array}{l}1998 \\
\text { Obs }\end{array}$ & $\begin{array}{l}\text { SSBF } \\
\text { Median }\end{array}$ & $\begin{array}{l}2003 \\
\text { Obs }\end{array}$ & $\begin{array}{l}\text { SSBF } \\
\text { Median }\end{array}$ \\
\hline All Firms & 3,224 & 0.177 & 4,637 & 0.251 & 3,485 & 0.092 & 4,163 & 0.074 \\
\hline \multicolumn{9}{|l|}{ Organizational Form } \\
\hline Proprietorship & 1,195 & 0.051 & 1,492 & 0.196 & 1,375 & 0.000 & 1,298 & 0.000 \\
\hline Partnership or LLP & 255 & 0.245 & 337 & 0.259 & 218 & 0.182 & 337 & 0.141 \\
\hline S-Corporation & 449 & 0.284 & 1,100 & 0.352 & 1,013 & 0.257 & 1,532 & 0.237 \\
\hline C-Corporation & 1,325 & 0.236 & 1,708 & 0.254 & 851 & 0.231 & 941 & 0.261 \\
\hline LLC & & N/A & & N/A & 28 & 0.538 & 55 & 0.169 \\
\hline \multicolumn{9}{|l|}{ Asset Quartile } \\
\hline 1 (Largest) & 806 & 0.273 & 1,160 & 0.207 & 871 & 0.215 & 1,040 & 0.206 \\
\hline 2 & 806 & 0.241 & 1,159 & 0.255 & 870 & 0.184 & 1,041 & 0.215 \\
\hline 3 & 806 & 0.181 & 1,159 & 0.266 & 871 & 0.129 & 1,041 & 0.115 \\
\hline 4 (Smallest) & 806 & 0.000 & 1,159 & 0.264 & 873 & 0.000 & 1,041 & 0.000 \\
\hline \multicolumn{9}{|l|}{ Firm Age } \\
\hline 0 - 5 Years & 861 & 0.294 & 956 & 0.364 & 890 & 0.087 & 820 & 0.141 \\
\hline $6-10$ Years & 738 & 0.189 & 1,152 & 0.280 & 707 & 0.161 & 797 & 0.128 \\
\hline $11-20$ Years & 921 & 0.177 & 1,433 & 0.235 & 1,050 & 0.106 & 1,235 & 0.062 \\
\hline $21+$ Years & 704 & 0.055 & 1,096 & 0.182 & 838 & 0.022 & 1,311 & 0.033 \\
\hline \multicolumn{9}{|l|}{ Race/Ethnicity } \\
\hline Asian & 63 & 0.144 & 308 & 0.248 & 199 & 0.036 & 165 & 0.111 \\
\hline Black & 53 & 0.084 & 442 & 0.211 & 259 & 0.027 & 119 & 0.000 \\
\hline Hispanic & 50 & 0.211 & 291 & 0.222 & 243 & 0.046 & 146 & 0.018 \\
\hline White & 2,984 & 0.188 & 3,559 & 0.256 & 2,745 & 0.098 & 3,616 & 0.074 \\
\hline Other & 74 & 0.091 & 37 & 0.237 & 39 & 0.154 & 117 & 0.512 \\
\hline \multicolumn{9}{|l|}{ Gender } \\
\hline Male & 2,822 & 0.187 & 3,797 & 0.254 & 2,722 & 0.110 & 3,275 & 0.111 \\
\hline Female & 402 & 0.114 & 840 & 0.226 & 763 & 0.006 & 888 & 0.000 \\
\hline
\end{tabular}


Table 4

Median Capital Structure Ratios by Selected Firm and Owner Characteristics Panel B: Capital Structure as Measured by the Ratio of Total Liabilities to Total Assets

(Data are taken from the 1987, 1993, 1998 and 2003 Surveys of Small Business Finances)

\begin{tabular}{|c|c|c|c|c|c|c|c|c|}
\hline Variables & $\begin{array}{l}1987 \\
\text { Obs }\end{array}$ & $\begin{array}{l}\text { SSBF } \\
\text { Median }\end{array}$ & $\begin{array}{l}1993 \\
\text { Obs }\end{array}$ & $\begin{array}{l}\text { SSBF } \\
\text { Median }\end{array}$ & $\begin{array}{l}1998 \\
\text { Obs }\end{array}$ & $\begin{array}{l}\text { SSBF } \\
\text { Median }\end{array}$ & $\begin{array}{l}2003 \\
\text { Obs }\end{array}$ & $\begin{array}{l}\text { SSBF } \\
\text { Median }\end{array}$ \\
\hline All Firms & 3,224 & 0.394 & 4,637 & 0.474 & 3,485 & 0.347 & 4,163 & 0.275 \\
\hline \multicolumn{9}{|l|}{ Organizational Form } \\
\hline Proprietorship & 1,195 & 0.223 & 1,492 & 0.414 & 1,375 & 0.111 & 1,298 & 0.080 \\
\hline Partnership or LLP & 255 & 0.414 & 337 & 0.428 & 218 & 0.400 & 337 & 0.313 \\
\hline S-Corporation & 449 & 0.542 & 1,100 & 0.578 & 1,013 & 0.558 & 1,532 & 0.500 \\
\hline C-Corporation & 1,325 & 0.481 & 1,708 & 0.515 & 851 & 0.536 & 941 & 0.555 \\
\hline LLC & & N/A & & N/A & 28 & 0.577 & 55 & 0.459 \\
\hline \multicolumn{9}{|l|}{ Asset Quartile } \\
\hline 1 (Largest) & 806 & 0.545 & 1,160 & 0.500 & 871 & 0.436 & 1,040 & 0.448 \\
\hline 2 & 806 & 0.444 & 1,159 & 0.448 & 870 & 0.414 & 1,041 & 0.386 \\
\hline 3 & 806 & 0.356 & 1,159 & 0.457 & 871 & 0.381 & 1,041 & 0.271 \\
\hline 4 (Smallest) & 806 & 0.222 & 1,159 & 0.512 & 873 & 0.025 & 1,041 & 0.069 \\
\hline \multicolumn{9}{|l|}{ Firm Age } \\
\hline $0-5$ Years & 861 & 0.529 & 956 & 0.563 & 890 & 0.421 & 820 & 0.451 \\
\hline $6-10$ Years & 738 & 0.414 & 1,152 & 0.500 & 707 & 0.411 & 797 & 0.322 \\
\hline $11-20$ Years & 921 & 0.372 & 1,433 & 0.460 & 1,050 & 0.348 & 1,235 & 0.260 \\
\hline $21+$ Years & 704 & 0.235 & 1,096 & 0.397 & 838 & 0.220 & 1,311 & 0.199 \\
\hline \multicolumn{9}{|l|}{ Race/Ethnicity } \\
\hline Asian & 63 & 0.367 & 308 & 0.453 & 199 & 0.213 & 165 & 0.386 \\
\hline Black & 53 & 0.193 & 442 & 0.471 & 259 & 0.185 & 119 & 0.240 \\
\hline Hispanic & 50 & 0.471 & 291 & 0.434 & 243 & 0.271 & 146 & 0.229 \\
\hline White & 2,984 & 0.401 & 3,559 & 0.478 & 2,745 & 0.362 & 3,616 & 0.273 \\
\hline Other & 74 & 0.273 & 37 & 0.512 & 39 & 0.387 & 117 & 0.709 \\
\hline \multicolumn{9}{|l|}{ Gender } \\
\hline Male & 2,822 & 0.396 & 3,797 & 0.477 & 2,722 & 0.370 & 3,275 & 0.314 \\
\hline Female & 402 & 0.364 & 840 & 0.470 & 763 & 0.226 & 888 & 0.169 \\
\hline
\end{tabular}


Table 5

WLS Regression Analysis Explaining Determinants of Capital Structure at Privately Held Firms Panel A: Capital Structure as measured by the Ratio of Total Loans to Total Assets

(Data are taken from the 1987, 1993, 1998 and 2003 Surveys of Small Business Finances)

(a, b and $\mathbf{c}$ indicate statistical significance at the $0.01,0.05$ and 0.10 levels, respectively.)

\section{SSBF}

Observations

F Value

Root MSE

Dep Mean

Adj R-Sq

Coeff Var

Variable

Intercept

Firm Characteristics

$\ln$ (Assets)

$\ln$ (Firm Age)

ROA

Cash to Assets

Tangible Assets to Assets

Employment Growth Pos.

Employment Growth Neg.

Trade Credit Paid Late

Number of Banks

Number of Nonbanks

C-Corporation

S-Corporation

LLC

Partnership or LLP

Race,Ethnicity,Sex

Female Owner

Black Owner

Asian Owner

Hispanic Owner

Industrial Classification

SIC 2

SIC 3

SIC 4

SIC 51

SIC 52

SIC 6

SIC 7

SIC 8
3,223

1993 SSBF

4,637

23.10

11.41

0.311

0.131

3673.19

Coef.

0.621

$-0.028$

$-0.06$

$-0.02$

$-0.347$

0.17

0.053

$-0.010$

0.047

0.049

0.065

0.085

0.149

0.07

0.070

0.024

$-0.06$

$-0.064$

$-0.029$

$-0.016$

0.023

0.025

$-0.002$

0.012

0.152

0.045

0.018

\begin{tabular}{r}
4,637 \\
\\
\\
\hline$\quad 24.06$ \\
11.47 \\
0.354 \\
0.099 \\
3235.92
\end{tabular}

3235.92

$-0.032$

$-0.053$

$-0.018$

$-0.283$

0.160

0.020

0.023

0.008

0.060

0.047

0.035

0.075

6.83 a

2.85

0.021

$-0.033$

$-0.069$

0.000

$-1.44$

$-1.69$

$-0.63$

$-0.44$

0.68

0.60

$-0.09$

0.57

5.03

$1.93 \mathrm{c}$

0.72
0.012

0.002

0.045

$-0.042$

0.003

0.119

0.017

0.036
Coef. t-stat

a

22.20

0.399

0.135

5569.71

Coef. t-stat

1.173

15.70

$\begin{array}{lll}-0.089 & -14.36 & \mathbf{a}\end{array}$

$-9.04 \quad \mathbf{a}$

$-6.93$

$-4.21 \quad \mathbf{a}$

$-12.16$

8.13

1.56

1.77 c

0.75

$8.81 \quad$ a

9.76 a

$2.59 \quad \mathrm{a}$

5.14 a

1.02

$-2.51 \quad b$

$-2.24 \quad b$

0.01

$\begin{array}{ll}-0.018 & -0.69\end{array}$
0.42

0.08

1.33

-1.88 c

0.14

$4.91 \quad$ a

0.95

1.89 c
$-0.048$

$-0.002$

$-0.199$

0.073

0.073

$\mathrm{n} / \mathrm{a}$

$\mathrm{n} / \mathrm{a}$

0.078

0.148

0.121

0.201

0.216

0.318

0.114

$-4.15 \quad \mathbf{a}$

$-0.21$

$-5.27 \quad \mathbf{a}$

2.03 b

$\begin{array}{rl} & \\ 3.36 & \mathbf{a} \\ 11.03 & \mathbf{a} \\ 13.16 & \mathbf{a} \\ 7.10 & \mathbf{a} \\ 8.34 & \mathbf{a} \\ 2.81 & \mathbf{a} \\ 2.81 & \mathbf{a}\end{array}$

$\begin{array}{ll}0.014 & 0.61\end{array}$

$-0.047$

$-0.028$

$-0.93$

$-0.57$

$-0.023$

$-0.54$

$-0.061 \quad-1.04$
-0.001

$-0.001 \quad-0.01$

0.13

$-0.069$

$-0.065$

2.24

$-1.47$

$-1.78$

0.071

1.47

$-0.080$

$-0.102$

$-2.28$

$-2.79$
2003 SSBF

4,163

a $\quad 18.58$

59.43

0.614

0.089

9676.90

Coef. t-stat

$3.122 \quad 16.61 \quad \mathbf{a}$

$\begin{array}{llll}-0.248 & -15.90 & \mathbf{a}\end{array}$

$\begin{array}{lll}-0.091 & -3.31 & \mathbf{a}\end{array}$

$\begin{array}{lll}-0.052 & -2.28 & \mathbf{b}\end{array}$

$\begin{array}{lll}-0.215 & -2.35 & \mathbf{b}\end{array}$

$0.103 \quad 1.10$

$0.006 \quad 0.08$

$\begin{array}{lll}0.396 & 4.30 & \mathbf{a}\end{array}$

$\begin{array}{lll}0.268 & 4.60 \quad \mathbf{a}\end{array}$

$\begin{array}{lll}0.110 & 3.42 \quad \mathbf{a}\end{array}$

$\begin{array}{lll}0.216 & 10.47 \quad \mathbf{a}\end{array}$

$\begin{array}{lll}0.481 & 6.12 & \mathbf{a}\end{array}$

$\begin{array}{rrr}0.406 & 6.79 & \mathbf{a}\end{array}$

$-0.006 \quad-0.03$

$\begin{array}{ll}0.252 & 2.72\end{array}$

$\begin{array}{lll}-0.289 & -5.08 & \mathbf{a}\end{array}$

$0.018 \quad 0.15$

$0.014 \quad 0.12$

$-0.110 \quad-0.93$

$0.015 \quad 0.10$

$-0.038 \quad-0.28$

$\begin{array}{lll}0.248 & 1.76 \quad \text { c }\end{array}$

$\begin{array}{lll}-0.221 & -1.81 \quad \text { c }\end{array}$

$-0.077 \quad-0.84$

$\begin{array}{ll}0.100 & 0.85\end{array}$

$-0.070 \quad-0.81$

$-0.017 \quad-0.18$ 
Table 5

WLS Regression Analysis Explaining Determinants of Capital Structure at Privately Held Firms

Panel B: Capital Structure as measured by the Ratio of Total Liabilities to Total Assets

(Data are taken from the 1987, 1993, 1998 and 2003 Surveys of Small Business Finances)

(a, $\mathbf{b}$ and $\mathbf{c}$ indicate statistical significance at the 0.01, 0.05 and 0.10 levels, respectively.)

\begin{tabular}{|c|c|c|c|c|c|c|c|c|c|c|c|c|}
\hline & \multicolumn{3}{|c|}{$1987 \mathrm{SSBF}$} & \multicolumn{3}{|c|}{$1993 \mathrm{SSBF}$} & \multicolumn{3}{|c|}{$1998 \mathrm{SSBF}$} & \multicolumn{2}{|c|}{2003 SSBF } & \\
\hline Observations & 3,223 & & & 4,637 & & & 3,484 & & \multicolumn{3}{|c|}{4,163} & \\
\hline F-Value & 29.99 & & $\mathbf{a}$ & 22.67 & & $\mathbf{a}$ & 24.21 & & $\mathbf{a}$ & 69.53 & & a \\
\hline Root MSE & 13.68 & & & 13.19 & & & 40.04 & & & 23.92 & & \\
\hline Dep Mean & 0.477 & & & 0.561 & & & 0.756 & & & 0.849 & & \\
\hline Adj R-Sq & 0.165 & & & 0.0932 & & & 0.133 & & & 0.112 & & \\
\hline Coeff Var & 2868.48 & & & 2350.70 & & & 5295.26 & & & 8190.35 & & \\
\hline Variable & Coef. & t-stat & & Coef. & t-stat & & Coef. & t-stat & & Coef. & t-stat & \\
\hline Intercept & 0.892 & 12.44 & $\mathbf{a}$ & 1.087 & 22.28 & $\mathbf{a}$ & 2.389 & 17.73 & $\mathbf{a}$ & 3.998 & 18.19 & a \\
\hline \multicolumn{12}{|l|}{ Firm Characteristics } & \\
\hline $\ln$ (Assets) & -0.042 & -6.96 & $\mathbf{a}$ & -0.049 & -12.18 & $\mathbf{a}$ & -0.163 & -14.49 & $\mathbf{a}$ & -0.323 & -17.71 & $\mathbf{a}$ \\
\hline ln (Firm Age) & -0.080 & -8.81 & $\mathbf{a}$ & -0.046 & -5.17 & $\mathbf{a}$ & -0.114 & -5.51 & $\mathbf{a}$ & -0.116 & -3.59 & $\mathbf{a}$ \\
\hline $\mathrm{ROA}$ & -0.052 & -5.13 & $\mathbf{a}$ & -0.002 & -0.37 & & 0.056 & 3.90 & $\mathbf{a}$ & -0.027 & -1.02 & \\
\hline Cash to Assets & -0.316 & -8.00 & $\mathbf{a}$ & -0.254 & -9.50 & $\mathbf{a}$ & -0.271 & -3.97 & $\mathbf{a}$ & -0.179 & -1.67 & c \\
\hline Tangible Assets to Assets & -0.058 & -1.61 & & 0.079 & 3.48 & $\mathbf{a}$ & -0.226 & -3.35 & $\mathbf{a}$ & -0.078 & -0.71 & \\
\hline Employment Growth Pos. & 0.002 & 0.10 & & 0.026 & 1.78 & & $\mathrm{n} / \mathrm{a}$ & & & 0.088 & 1.08 & \\
\hline Employment Growth Neg. & 0.074 & 3.14 & $\mathbf{a}$ & 0.039 & 2.57 & b & $\mathrm{n} / \mathrm{a}$ & & & 0.426 & 3.96 & $\mathbf{a}$ \\
\hline Trade Credit Paid Late & 0.124 & 7.73 & $\mathbf{a}$ & 0.079 & 6.12 & $\mathbf{a}$ & 0.312 & 7.45 & $\mathbf{a}$ & 0.462 & 6.79 & $\mathbf{a}$ \\
\hline Number of Banks & 0.068 & 6.40 & $\mathbf{a}$ & 0.054 & 6.81 & $\mathbf{a}$ & 0.193 & 7.98 & $\mathbf{a}$ & 0.152 & 4.05 & $\mathbf{a}$ \\
\hline Number of Nonbanks & 0.075 & 9.31 & $\mathbf{a}$ & 0.049 & 8.77 & $\mathbf{a}$ & 0.162 & 9.80 & $\mathbf{a}$ & 0.255 & 10.58 & $\mathbf{a}$ \\
\hline C-Corporation & 0.178 & 9.34 & $\mathbf{a}$ & 0.107 & 6.82 & $\mathbf{a}$ & 0.381 & 7.45 & $\mathbf{a}$ & 0.710 & 7.72 & $\mathbf{a}$ \\
\hline S-Corporation & 0.228 & 8.74 & $\mathbf{a}$ & 0.143 & 8.50 & $\mathbf{a}$ & 0.335 & 7.16 & $\mathbf{a}$ & 0.614 & 8.78 & $\mathbf{a}$ \\
\hline LLC & $\mathrm{n} / \mathrm{a}$ & & & $\mathrm{n} / \mathrm{a}$ & & & 0.490 & 2.40 & b & 0.315 & 1.31 & \\
\hline Partnership or LLP & 0.115 & 3.89 & $\mathbf{a}$ & 0.047 & 2.02 & b & 0.166 & 2.28 & b & 0.403 & 3.72 & $\mathbf{a}$ \\
\hline \multicolumn{12}{|l|}{ Race,Ethnicity,Sex } & \\
\hline Female Owner & 0.033 & 1.48 & & -0.018 & -1.19 & & -0.016 & -0.38 & & -0.333 & -5.01 & $\mathbf{a}$ \\
\hline Black Owner & -0.117 & -2.31 & $\mathbf{b}$ & -0.033 & -0.94 & & -0.108 & -1.19 & & 0.109 & 0.74 & \\
\hline Asian Owner & -0.035 & -0.77 & & -0.009 & -0.28 & & -0.131 & -1.50 & & 0.015 & 0.11 & \\
\hline Hispanic Owner & 0.030 & 0.55 & & -0.008 & -0.27 & & -0.099 & -1.28 & & -0.134 & -0.97 & \\
\hline \multicolumn{12}{|l|}{ Industrial Classification } & \\
\hline SIC 2 & -0.039 & -0.92 & & -0.018 & -0.52 & & -0.266 & -2.53 & b & -0.061 & -0.34 & \\
\hline SIC 3 & 0.006 & 0.15 & & 0.014 & 0.43 & & -0.218 & -2.26 & b & -0.023 & -0.14 & \\
\hline SIC 4 & -0.073 & -1.49 & & 0.047 & 1.20 & & 0.134 & 1.27 & & 0.244 & 1.47 & \\
\hline SIC 51 & 0.066 & 2.05 & $\mathbf{b}$ & -0.002 & -0.06 & & -0.130 & -1.55 & & -0.201 & -1.41 & \\
\hline SIC 52 & -0.024 & -0.94 & & -0.032 & -1.58 & & -0.255 & -3.87 & $\mathbf{a}$ & -0.113 & -1.06 & \\
\hline SIC 6 & 0.137 & 3.77 & $\mathbf{a}$ & 0.076 & 2.74 & $\mathbf{a}$ & -0.100 & -1.15 & & 0.062 & 0.45 & \\
\hline SIC 7 & 0.017 & 0.62 & & -0.015 & -0.73 & & -0.266 & -4.22 & $\mathbf{a}$ & -0.140 & -1.39 & \\
\hline SIC 8 & -0.036 & -1.19 & & -0.028 & -1.27 & & -0.277 & -4.20 & $\mathbf{a}$ & -0.026 & -0.25 & \\
\hline
\end{tabular}


Table 6

WLS Regression Analysis Explaining Determinants of Capital Structure at Privately Held Corporations Panel A: Capital Structure as measured by the Ratio of Total Loans to Total Assets Data are taken from the 1987, 1993, 1998 and 2003 Surveys of Small Business Finances a, b indicate statistical significance at the 0.01 and 0.05 levels, respectively.

\begin{tabular}{|c|c|c|c|c|}
\hline & $1987 \mathrm{SSBF}$ & 1993 SSBF & 1998 SSBF & 2003 SSBF \\
\hline Number of Observations & 1,772 & 2,704 & 1,864 & 2,473 \\
\hline F Value & 14.00 & 20.87 & 17.29 & 20.16 \\
\hline Root MSE & 11.40 & 9.93 & 20.44 & 53.43 \\
\hline Dep Mean & 0.353 & 0.386 & 0.491 & 0.747 \\
\hline Adj R-Sq & 0.139 & 0.139 & 0.149 & 0.146 \\
\hline
\end{tabular}

\begin{tabular}{|c|c|c|c|c|c|c|c|c|}
\hline Variable & Coef. & t-stat & Coef. & t-stat & Coef. & t-stat & Coef. & t-stat \\
\hline Intercept & 0.981 & $10.90 \mathbf{a}$ & 0.712 & $11.29 \mathbf{a}$ & 1.846 & $15.54 \mathbf{a}$ & 4.525 & $16.01 \mathbf{a}$ \\
\hline \multicolumn{9}{|l|}{ Firm Characteristics } \\
\hline $\ln$ (Assets) & -0.050 & $-7.43 \mathbf{a}$ & -0.037 & $-8.24 \mathbf{a}$ & -0.124 & $-14.47 \mathbf{a}$ & -0.342 & $-16.05 \mathbf{a}$ \\
\hline $\ln ($ Firm Age) & -0.071 & $-6.62 \mathbf{a}$ & -0.051 & $-5.03 \mathbf{a}$ & -0.040 & $-2.44 \mathbf{b}$ & -0.105 & $-2.77 \mathbf{a}$ \\
\hline ROA & -0.048 & $-3.90 \mathbf{a}$ & -0.035 & $-5.46 \mathbf{a}$ & 0.000 & -0.03 & -0.196 & $-6.01 \mathbf{a}$ \\
\hline Cash to Assets & -0.228 & $-4.00 \mathbf{a}$ & -0.217 & $-5.32 \mathbf{a}$ & -0.324 & $-4.93 \mathbf{a}$ & -0.110 & -0.73 \\
\hline Tangible Assets to Assets & 0.208 & $5.20 \mathrm{a}$ & 0.274 & $10.10 \mathbf{a}$ & 0.170 & $3.33 \mathbf{a}$ & 0.279 & $2.42 \mathrm{~b}$ \\
\hline Employment Growth Positive & -0.018 & -0.85 & 0.037 & $2.27 \mathrm{~b}$ & $\mathrm{n} / \mathrm{a}$ & $\mathrm{n} / \mathrm{a}$ & 0.067 & 0.81 \\
\hline Employment Growth Negative & 0.051 & $1.98 \mathbf{b}$ & 0.035 & $2.00 \mathrm{~b}$ & $\mathrm{n} / \mathrm{a}$ & $\mathrm{n} / \mathrm{a}$ & 0.656 & $5.80 \mathbf{a}$ \\
\hline Trade Credit Paid Late & 0.059 & $3.20 \mathbf{a}$ & 0.036 & $2.61 \mathbf{a}$ & 0.113 & $3.78 \mathbf{a}$ & 0.287 & $3.89 \mathbf{a}$ \\
\hline Number of Banks & 0.030 & $2.67 \mathbf{a}$ & 0.032 & $3.91 \mathbf{a}$ & 0.101 & $5.65 \mathbf{a}$ & 0.110 & $2.76 \mathbf{a}$ \\
\hline Number of Nonbanks & 0.047 & $5.15 \mathbf{a}$ & 0.029 & $5.38 \mathbf{a}$ & 0.069 & $5.74 \mathbf{a}$ & 0.138 & $5.65 \mathrm{a}$ \\
\hline
\end{tabular}

Race, Ethnicity, Sex

Female Owner

Black Owner

$-0.055-1.70$

$-0.055$

$-3.19 \mathbf{a}$

0.04

1.40

$\begin{array}{ll}-0.214 & -2.70 \mathbf{a}\end{array}$

$\begin{array}{ll}-0.029 & -0.39\end{array}$

$-0.044$

$-0.93$

$-0.113$

$-1.49$

$-0.431 \quad-2.00 \mathbf{b}$

Asian Owner

$-0.054 \quad-0.95$

$-0.022$

$-0.60$

$-0.138$

$-1.97 \mathrm{~b}$

$-0.293$

$-2.05 \mathbf{b}$

Hispanic Owner

$0.012 \quad 0.18$

$-0.028$

$-0.43$

$-0.259$

$-1.61$

SIC 2

$\begin{array}{cc}0.004 & 0.09\end{array}$

0.066

1.89

$\begin{array}{ll}-0.064 & -0.83\end{array}$

$\begin{array}{ll}0.005 & 0.07\end{array}$

0.401

$2.13 \mathrm{~b}$

$\begin{array}{ll}-0.029 & -0.69\end{array}$

0.034

1.07

0.053

0.72

0.090

0.56

SIC 4

$\begin{array}{ll}0.018 & 0.36 \\ -0.046 & -1.34\end{array}$

0.068

1.77
-1.45

$-0.066$

$-1.13$

0.490

2.77 a

$-0.044 \quad-1.34$

0.017

-1.45
0.73

$-0.127$

$-2.38 \mathrm{~b}$

0.076

0.55

SIC 52

$0.095 \quad 2.27 \mathbf{b}$

2.70 a

0.002

0.03

$\begin{array}{ll}0.039 & 1.63\end{array}$

$-0.14$

$-2.78 \mathbf{a}$

0.072

0.60

$-0.038 \quad-1.13$

0.080

2.99 a

$\begin{array}{ll}-0.121 & -2.23 \mathbf{b}\end{array}$

0.039

0.98

SIC 8

$\begin{array}{ll}-0.065 & -1.65\end{array}$

0.141

0.34
1.18 
Table 6

WLS Regression Analysis Explaining Determinants of Capital Structure at Privately Held Corporations Panel B: Capital Structure as measured by the Ratio of Total Liabilities to Total Assets

Data are taken from the 1987, 1993, 1998 and 2003 Surveys of Small Business Finances a, b indicate statistical significance at the 0.01 and 0.05 levels, respectively.

\begin{tabular}{|c|c|c|c|c|c|c|c|c|}
\hline & \multicolumn{2}{|l|}{$1987 \mathrm{SSBF}$} & \multicolumn{2}{|l|}{1993 SSBF } & \multicolumn{2}{|l|}{1998 SSBF } & \multicolumn{2}{|l|}{2003 SSBF } \\
\hline Observations & \multicolumn{2}{|l|}{1,772} & \multicolumn{2}{|l|}{2,704} & \multicolumn{2}{|l|}{1,864} & \multicolumn{2}{|l|}{2,473} \\
\hline F-Value & \multicolumn{2}{|l|}{14.18} & \multicolumn{2}{|l|}{14.13} & \multicolumn{2}{|l|}{17.77} & \multicolumn{2}{|l|}{$2 . .21$} \\
\hline Root MSE & \multicolumn{2}{|l|}{13.92} & \multicolumn{2}{|l|}{11.90} & \multicolumn{2}{|l|}{35.07} & \multicolumn{2}{|l|}{62.66} \\
\hline Dep Mean & \multicolumn{2}{|l|}{0.567} & \multicolumn{2}{|l|}{0.617} & \multicolumn{2}{|l|}{0.892} & \multicolumn{2}{|l|}{1.050} \\
\hline Adj R-Sq & 0.141 & & 965 & & 0.153 & & \multicolumn{2}{|l|}{0.165} \\
\hline Variable & Coef. & t-stat & Coef. & t-stat & Coef. & t-stat & Coef. & t-stat \\
\hline Intercept & 1.561 & $14.21 \mathbf{a}$ & 1.159 & $15.34 \mathbf{a}$ & 3.357 & $16.47 \mathbf{a}$ & 5.899 & $17.80 \mathbf{a}$ \\
\hline \multicolumn{9}{|l|}{ Firm Characteristics } \\
\hline $\ln$ (Assets) & -0.065 & $-7.93 \mathbf{a}$ & -0.054 & $-9.92 \mathbf{a}$ & -0.196 & $-13.41 \mathbf{a}$ & -0.441 & $-18.14 \mathbf{a}$ \\
\hline $\ln$ (Firm Age) & -0.093 & $-7.06 \mathbf{a}$ & -0.049 & $-4.04 \mathbf{a}$ & -0.093 & $-3.34 \mathbf{a}$ & -0.112 & $-2.51 \mathbf{b}$ \\
\hline ROA & -0.093 & $-6.14 \mathbf{a}$ & -0.118 & $-2.29 \mathbf{b}$ & 0.069 & $3.41 \mathbf{a}$ & -0.206 & $-5.41 \mathbf{a}$ \\
\hline Cash to Assets & -0.318 & $-5.51 \mathbf{a}$ & -0.198 & $-4.07 \mathbf{a}$ & -0.596 & $-5.29 \mathbf{a}$ & 0.067 & -0.38 \\
\hline Tangible Assets to Assets & -0.040 & -0.81 & 0.163 & $5.00 \mathrm{a}$ & -0.028 & -0.32 & 0.045 & 0.33 \\
\hline Employment Growth Positive & -0.010 & -0.40 & 0.052 & $2.65 \mathbf{a}$ & $\mathrm{n} / \mathrm{a}$ & $\mathrm{n} / \mathrm{a}$ & 0.215 & 2.24 \\
\hline Employment Growth Negative & 0.068 & $2.13 \mathrm{~b}$ & 0.053 & $2.57 \mathbf{b}$ & $\mathrm{n} / \mathrm{a}$ & $\mathrm{n} / \mathrm{a}$ & 0.732 & $5.51 \mathbf{a}$ \\
\hline Trade Credit Paid Late & 0.124 & $5.74 \mathbf{a}$ & 0.095 & $5.70 \mathrm{a}$ & 0.311 & $6.05 \mathbf{a}$ & 0.523 & $6.04 \mathbf{a}$ \\
\hline Number of Banks & 0.050 & $3.65 \mathbf{a}$ & 0.037 & $3.73 \mathbf{a}$ & 0.133 & $4.35 \mathbf{a}$ & 0.174 & $3.72 \mathbf{a}$ \\
\hline Number of Nonbanks & 0.054 & $4.78 \mathbf{a}$ & 0.037 & $5.68 \mathbf{a}$ & 0.091 & $4.42 \mathbf{a}$ & 0.173 & $6.02 \mathbf{a}$ \\
\hline \multicolumn{9}{|l|}{ Race, Ethnicity and Gender } \\
\hline Female Owner & -0.016 & -0.48 & -0.019 & -0.93 & 0.113 & 1.89 & -0.311 & $-3.34 \mathbf{a}$ \\
\hline Black Owner & -0.075 & $-0.81 \mathbf{b}$ & -0.012 & -0.21 & -0.224 & -1.72 & -0.248 & -0.98 \\
\hline Asian Owner & -0.131 & -1.90 & -0.061 & -1.42 & -0.252 & $-2.09 \mathbf{b}$ & -0.341 & $-2.03 \mathbf{b}$ \\
\hline Hispanic Owner & 0.085 & 1.06 & 0.074 & 1.62 & -0.081 & -0.71 & -0.369 & $-1.96 \mathbf{b}$ \\
\hline \multicolumn{9}{|l|}{ Industrial Classification } \\
\hline SIC 2 & -0.040 & -0.73 & 0.019 & 0.47 & -0.321 & $-2.42 \mathbf{b}$ & 0.410 & 1.86 \\
\hline SIC 3 & -0.062 & -1.23 & 0.020 & 0.53 & -0.170 & -1.46 & 0.216 & 1.15 \\
\hline SIC 4 & -0.083 & -1.32 & 0.043 & 1.01 & 0.041 & 0.33 & 0.426 & $2.05 \mathrm{~b}$ \\
\hline SIC 51 & 0.014 & 0.34 & 0.002 & 0.05 & 0.148 & -1.47 & 0.152 & 0.94 \\
\hline SIC 52 & -0.074 & -1.84 & -0.002 & -0.07 & -0.328 & $-3.57 \mathbf{a}$ & 0.159 & 1.14 \\
\hline SIC 6 & 0.079 & 1.54 & 0.023 & $0.63 \mathbf{a}$ & -0.145 & -1.28 & 0.101 & 0.53 \\
\hline SIC 7 & -0.086 & $-2.08 \mathbf{b}$ & -0.013 & -0.44 & -0.366 & $-4.16 \mathbf{a}$ & -0.019 & -0.14 \\
\hline SIC 8 & -0.169 & $-3.52 \mathbf{a}$ & -0.029 & -0.93 & -0.301 & $-3.25 \mathbf{a}$ & 0.093 & 0.67 \\
\hline
\end{tabular}


Appendix Table A1

Descriptive Statistics for Variables Used to Explain Determinants of Capital Structure

Panel A: 1987 SSBF

Variable

Loans to Assets

Liabilities to Asset

Assets

Sales

Employment

Firm Age

ROA

Cash to Assets

Tangible Assets to Assets

Employment Growth is Pos.

Employment Growth is Neg.

Trade Credit Paid Late

Number of Banks

Number of Nonbanks

Number of Fin'l Institutions

C-Corporation

S-Corporation

Partnership or LLP

Proprietorship

Female Owner

Asian Owner

Black Owner

Hispanic Owner

SIC1

SIC2

SIC3

SIC4

SIC51

SIC52

SIC6

SIC7

SIC8

Median
0.177
0.394
99,000
250,000
4
10
0.207
0.085
0.667
0
0
0
1
0
2
0
0
0
0
0
0
0
0
0
0
0
0
0
0
0
0
0
0
0
0
0
0
0
0
0
0
0

\section{Mean}

0.312

0.478

476,254

$1,251,382$

11.145

13.265

0.557

0.162

0.615

0.242

0.125

0.420

1.317

0.725

2.042

0.392

0.124

0.081

0.403

0.138

0.023

0.030

0.020

0.131

0.042

0.048

0.029

0.100

0.264

0.068

0.184

0.132
Std Error

0.007

0.008

43, 080

108,277

0.484

0.207

0.014

0.004

0.005

0.007

0.006

0.009

0.013

0.017

0.023

0.009

0.006

0.005

0.009

0.006

0.003

0.003

0.002

0.006

0.004

0.004

0.003

0.005

0.008

0.004

0.007

0.006

\begin{tabular}{|c|c|}
\hline Minimum & Maximum \\
\hline 0 & 1.89 \\
\hline 0 & 2.58 \\
\hline 0 & $154,087,353$ \\
\hline 180 & $202,000,000$ \\
\hline 0.5 & 475 \\
\hline 0 & 118 \\
\hline-0.325 & 2.38 \\
\hline-0.044 & 1 \\
\hline 0.005 & 1 \\
\hline 0 & 1 \\
\hline 0 & 1 \\
\hline 0 & 1 \\
\hline 0 & 12 \\
\hline 0 & 11 \\
\hline 0 & 12 \\
\hline 0 & 1 \\
\hline 0 & 1 \\
\hline 0 & 1 \\
\hline 0 & 1 \\
\hline 0 & 1 \\
\hline 0 & 1 \\
\hline 0 & 1 \\
\hline 0 & 1 \\
\hline 0 & 1 \\
\hline 0 & 1 \\
\hline 0 & 1 \\
\hline 0 & 1 \\
\hline 0 & 1 \\
\hline 0 & 1 \\
\hline 0 & 1 \\
\hline 0 & 1 \\
\hline 0 & 1 \\
\hline
\end{tabular}




\section{Appendix Table A1 \\ Descriptive Statistics for Variables Used to Explain Determinants of Capital Structure \\ Panel B: 1993 SSBF}

\section{Variable}

Loans to Assets

Liabilities to Asset

Assets

Sales

Employment

Firm Age

ROA

Cash to Assets

Tangible Assets to Assets

Employment Growth is Pos.

Employment Growth is Neg.

Bus Delinquencies

Trade Credit Paid Late

Number of Banks

Number of Nonbanks

Number of Fin'l Institutions

C-Corporation

S-Corporation

Partnership or LLP

Proprietorship

Female Owner

Asian Owner

Black Owner

Hispanic Owner

SIC1

$\mathrm{SIC} 2$

SIC3

SIC4

SIC51

SIC52

SIC6

SIC7

SIC8

Median
0.2513755
0.4737549
69,435
190,000
3
11
0.213
0.108
0.700
0
0
0
0
1
1
2
0
0
0
0
0
0
0
0
0
0
0
0
0
0
0
0
0
0
0
0
0
0
0
0
0
0

\section{Mean}

0.354

0.561

488,844

$1,001,330$

8.494

14.284

0.690

0.197

0.656

0.377

0.268

0.190

0.363

1.262

0.844

2.106

0.284

0.203

0.080

0.432

0.206

0.036

0.029

0.043

0.142

0.039

0.042

0.028

0.085

0.217

0.071

0.211

0.166
Std Erro

0.005

0.006

40,729

64,368

0.336

0.178

0.019

0.004

0.004

0.007

0.007

0.006

0.007

0.012

0.017

0.021

0.007

0.006

0.004

0.007

0.006

0.003

0.002

0.003

0.005

0.003

0.003

0.002

0.004

0.006

0.004

0.006

0.005

\section{Minimum}

0

0

0

0

0.5

0

$-1.05$

$-0.026$

0.000

\section{0}

0

0

0
0

0

0

0

0

0

0

0

0

0

0
0

0
0

Maximum

1.21
1.59
$238,655,000$
$335,660,000$
495
216
4.23
1
1.000

1.000 
Appendix Table A1

Descriptive Statistics for Variables Used to Explain Determinants of Capital Structure Panel C: 1998 SSBF

$\quad$ Variable
Loans to Assets
Liabilities to Asset
Assets
Sales
Employment
Firm Age
ROA
Cash to Assets
Bus Delinquencies
Trade Credit Paid Late
Number of Banks
Number of Nonbanks
Number of Fin'1 Institutions
C-Corporation
S-Corporation
LLC
Partnership or LLP
Proprietorship
Female Owner
Asian Owner
Black Owner
Hispanic Owner
SIC1
SIC2
SIC3
SIC4
SIC51
SIC52
SIC6

Median
0.09
0.34
58,113
160,000
0.33
0.11

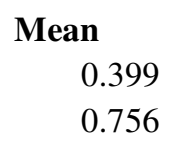

Std Error

0.011
0.019

34,339

109,076

0.398

0.188

0.023

0.005

0.006

0.008

0.013

0.019

0.024

0.007

0.007

0.001

0.004

0.008

0.007

0.003

0.003

0.004

0.005

0.003

0.004

0.003

0.004

0.007

0.004

0.007

0.007

\begin{tabular}{rr} 
Minimum & \multicolumn{1}{c}{ Maximum } \\
0 & 2.27 \\
0 & 4.26
\end{tabular}

$\begin{array}{rr}10 & 99,912,000 \\ 0 & 624,000,000 \\ 1 & 482 \\ 0 & 104 \\ -1.45 & 3.74 \\ -0.052 & 1 \\ 0 & 1 \\ 0 & 1\end{array}$

13

15

20

1

1

1

1

1

1

1

1

1

1

1

1

1

1

1

1

1 


\section{Appendix Table A1 \\ Descriptive Statistics for Variables Used to Explain Determinants of Capital Structure Panel D: 2003 SSBF}

$\quad$ Variable
Loans to Assets
Liabilities to Asset
Assets
Sales
Employment
Firm Age
ROA
Cash to Assets
Tangible Assets to Assets
Employment Growth Positive
Employment Growth Negative
Bus Delinquencies
Trade Credit Paid Late
Number of Banks
Number of Nonbanks
Number of Fin'l Institutions
C-Corporation
S-Corporation
LLC
Partnership or LLP
Proprietorship
Female Owner
Asian Owner
Black Owner
Hispanic Owner
SIC1
SIC2
SIC3
SIC4
SIC51
SIC52
SIC6
SIC7
SIC8

Median
0.074
0.275
72,000
200,000
3
12
0.287
0.105
0.545
0
0
0
0
1
1
2
0
0
0
0
0
0
0
0
0
0
0
0
0
0
0
0

\begin{tabular}{|c|c|}
\hline Mean & Std Error \\
\hline 0.614 & 0.025 \\
\hline 0.849 & 0.030 \\
\hline 567,881 & 47,831 \\
\hline $1,098,386$ & 73,880 \\
\hline 8.736 & 0.333 \\
\hline 14.381 & 0.172 \\
\hline 0.749 & 0.018 \\
\hline 0.225 & 0.004 \\
\hline 0.513 & 0.005 \\
\hline 0.154 & 0.006 \\
\hline 0.077 & 0.006 \\
\hline 0.159 & 0.006 \\
\hline 0.247 & 0.007 \\
\hline 1.246 & 0.013 \\
\hline 1.165 & 0.019 \\
\hline 2.411 & 0.024 \\
\hline 0.146 & 0.005 \\
\hline 0.314 & 0.007 \\
\hline 0.014 & 0.002 \\
\hline 0.086 & 0.004 \\
\hline 0.440 & 0.008 \\
\hline 0.258 & 0.007 \\
\hline 0.045 & 0.003 \\
\hline 0.038 & 0.003 \\
\hline 0.043 & 0.003 \\
\hline 0.116 & 0.005 \\
\hline 0.031 & 0.003 \\
\hline 0.041 & 0.003 \\
\hline 0.039 & 0.003 \\
\hline 0.060 & 0.004 \\
\hline 0.186 & 0.006 \\
\hline 0.070 & 0.004 \\
\hline 0.249 & 0.007 \\
\hline 0.207 & 0.006 \\
\hline
\end{tabular}

\begin{tabular}{|c|c|}
\hline Minimum & Maximum \\
\hline 0 & 11.3 \\
\hline 0 & 12.8 \\
\hline 16 & $235,027,709$ \\
\hline 0 & $210,861,289$ \\
\hline 0 & 486 \\
\hline 1 & 103 \\
\hline-1.000 & 3.000 \\
\hline-0.080 & 1.000 \\
\hline 0.000 & 1.000 \\
\hline 0 & 1 \\
\hline 0 & 1 \\
\hline 0 & 1 \\
\hline 0 & 1 \\
\hline 0 & 20 \\
\hline 0 & 11 \\
\hline 0 & 20 \\
\hline 0 & 1 \\
\hline 0 & 1 \\
\hline 0 & 1 \\
\hline 0 & 1 \\
\hline 0 & 1 \\
\hline 0 & 1 \\
\hline 0 & 1 \\
\hline 0 & 1 \\
\hline 0 & 1 \\
\hline 0 & 1 \\
\hline 0 & 1 \\
\hline 0 & 1 \\
\hline 0 & 1 \\
\hline 0 & 1 \\
\hline 0 & 1 \\
\hline 0 & 1 \\
\hline 0 & 1 \\
\hline 0 & 1 \\
\hline
\end{tabular}




\section{Appendix Table A2A \\ Capital Ratios by Selected Firm and Owner Characteristics \\ Data from 1987 SSBF \\ Panel A: Capital Structure as Measured by the Ratio of Loans to Assets}

\begin{tabular}{|c|c|c|c|c|}
\hline Variable & Obs. & Median & Mean & Std Error \\
\hline Loans to Assets & 3,224 & 0.177 & 0.312 & 0.007 \\
\hline Organizational Form & Obs & Median & Mean & Std Error \\
\hline Proprietorship & 1,195 & 0.051 & 0.253 & 0.011 \\
\hline Partnership or LLP & 255 & 0.245 & 0.340 & 0.023 \\
\hline S-Corporation & 449 & 0.284 & 0.414 & 0.022 \\
\hline C-Corporation & 1,325 & 0.236 & 0.334 & 0.010 \\
\hline \multicolumn{5}{|l|}{ LLC } \\
\hline Asset Quartile & Obs & Median & Mean & Std Error \\
\hline 1 (Largest) & 806 & 0.273 & 0.345 & 0.011 \\
\hline 2 & 806 & 0.241 & 0.334 & 0.012 \\
\hline 3 & 806 & 0.181 & 0.300 & 0.012 \\
\hline 4 (Smallest) & 806 & 0.000 & 0.288 & 0.017 \\
\hline Firm Age & Obs & Median & Mean & Std Error \\
\hline $0-5$ Years & 861 & 0.294 & 0.390 & 0.014 \\
\hline $6-10$ Years & 738 & 0.189 & 0.331 & 0.016 \\
\hline $11-20$ Years & 921 & 0.177 & 0.285 & 0.011 \\
\hline $21+$ Years & 704 & 0.055 & 0.213 & 0.013 \\
\hline Race/Ethnicity & Obs & Median & Mean & Std Error \\
\hline Asian & 63 & 0.144 & 0.310 & 0.054 \\
\hline Black & 53 & 0.084 & 0.252 & 0.046 \\
\hline Hispanic & 50 & 0.211 & 0.310 & 0.046 \\
\hline White & 2,984 & 0.188 & 0.316 & 0.007 \\
\hline Other & 74 & 0.091 & 0.183 & 0.029 \\
\hline Gender & Obs & Median & Mean & Std Error \\
\hline Male & 2,822 & 0.187 & 0.312 & 0.007 \\
\hline Female & 402 & 0.114 & 0.311 & 0.021 \\
\hline
\end{tabular}




\section{Appendix Table A2A \\ Capital Ratios by Selected Firm and Owner Characteristics \\ Data from 1987 SSBF}

Panel B: Capital Structure as Measured by the Ratio of Liabilities to Assets

\begin{tabular}{|c|c|c|c|c|}
\hline Variable & Obs. & Median & Mean & Std Error \\
\hline Liabilities to Assets & 3,224 & 0.394 & 0.478 & 0.008 \\
\hline Organizational Form & Obs & Median & Mean & Std Error \\
\hline Proprietorship & 1,195 & 0.223 & 0.362 & 0.012 \\
\hline Partnership or LLP & 255 & 0.414 & 0.488 & 0.029 \\
\hline S-Corporation & 449 & 0.542 & 0.618 & 0.025 \\
\hline C-Corporation & 1,325 & 0.481 & 0.551 & 0.013 \\
\hline \multicolumn{5}{|l|}{ LLC } \\
\hline Asset Quartile & Obs & Median & Mean & Std Error \\
\hline 1 (Largest) & 806 & 0.545 & 0.561 & 0.012 \\
\hline 2 & 806 & 0.444 & 0.503 & 0.014 \\
\hline 3 & 806 & 0.356 & 0.449 & 0.015 \\
\hline 4 (Smallest) & 806 & 0.222 & 0.444 & 0.021 \\
\hline Firm Age & Obs & Median & Mean & Std Error \\
\hline 0 - 5 Years & 861 & 0.529 & 0.576 & 0.017 \\
\hline $6-10$ Years & 738 & 0.414 & 0.513 & 0.019 \\
\hline $11-20$ Years & 921 & 0.372 & 0.441 & 0.014 \\
\hline $21+$ Years & 704 & 0.235 & 0.347 & 0.015 \\
\hline Race/Ethnicity & Obs & Median & Mean & Std Error \\
\hline Asian & 63 & 0.367 & 0.501 & 0.065 \\
\hline Black & 53 & 0.193 & 0.345 & 0.048 \\
\hline Hispanic & 50 & 0.471 & 0.534 & 0.062 \\
\hline White & 2,984 & 0.401 & 0.484 & 0.009 \\
\hline Other & 74 & 0.273 & 0.312 & 0.032 \\
\hline Gender & Obs & Median & Mean & Std Error \\
\hline Male & 2,822 & 0.396 & 0.479 & 0.009 \\
\hline Female & 402 & 0.364 & 0.474 & 0.026 \\
\hline
\end{tabular}




\section{Appendix Table A2B \\ Capital Ratios by Selected Firm and Owner Characteristics \\ Data from 1993 SSBF \\ Panel A: Capital Structure as Measured by the Ratio of Loans to Assets}

$\begin{array}{lrrrr}\text { Variable } & & \text { Median } & \text { Mean } & \text { Std Error } \\ \text { Loans to Assets } & & 0.251 & 0.354 & 0.005 \\ & & & & \\ \text { Organizational Form } & \text { Obs } & \text { Median } & \text { Mean } & \text { Std Error } \\ \text { Proprietorship } & 1,492 & 0.196 & 0.323 & 0.009 \\ \text { Partnership or LLP } & 337 & 0.259 & 0.347 & 0.020 \\ \text { S-Corporation } & 1,100 & 0.352 & 0.420 & 0.011 \\ \text { C-Corporation } & 1,708 & 0.254 & 0.358 & 0.009 \\ \text { LLC } & & & & \\ & & & & \\ \text { Asset Quartile } & \text { Obs } & \text { Median } & \text { Mean } & \text { Std Error } \\ \text { 1 (Largest) } & 1,160 & 0.207 & 0.357 & 0.012 \\ 2 & 1,159 & 0.255 & 0.358 & 0.011 \\ 3 & 1,159 & 0.266 & 0.349 & 0.010 \\ 4 \text { (Smallest) } & 1,159 & 0.264 & 0.345 & 0.009 \\ & & & & \\ \text { Firm Age } & \text { Obs } & \text { Median } & \text { Mean } & \text { Std Error } \\ \text { 0 - 5 Years } & 956 & 0.364 & 0.419 & 0.013 \\ \text { 6 - 10 Years } & 1,152 & 0.280 & 0.365 & 0.011 \\ \text { 11 - 20 Years } & 1,433 & 0.235 & 0.338 & 0.009 \\ \text { 21 + Years } & 1,096 & 0.182 & 0.299 & 0.011 \\ & & & & \\ \text { Race/Ethnicity } & \text { Obs } & \text { Median } & \text { Mean } & \text { Std Error } \\ \text { Asian } & 308 & 0.248 & 0.353 & 0.021 \\ \text { Black } & \text { Obs } & \text { Median } & \text { Mean } & \text { Std Error } \\ \text { Hispanic } & 3,797 & 0.254 & 0.357 & 0.006 \\ \text { White } & 840 & 0.226 & 0.344 & 0.013 \\ \text { Other } & 291 & 0.211 & 0.313 & 0.017 \\ & 3,559 & 0.256 & 0.321 & 0.021 \\ \text { Gender } & 37 & 0.237 & 0.343 & 0.006 \\ \text { Male } & & & & 0.065 \\ \text { Female } & & & \end{array}$




\section{Appendix Table A2B \\ Capital Ratios by Selected Firm and Owner Characteristics \\ Data from 1993 SSBF}

Panel B: Capital Structure as Measured by the Ratio of Liabilities to Assets

\begin{tabular}{|c|c|c|c|c|}
\hline \multirow{2}{*}{$\begin{array}{l}\text { Variable } \\
\text { Liabilities to Assets }\end{array}$} & & \multirow{2}{*}{$\begin{array}{r}\text { Median } \\
0.474\end{array}$} & \multirow{2}{*}{$\begin{array}{l}\text { Mean } \\
0.561\end{array}$} & \multirow{2}{*}{$\begin{array}{r}\text { Std Error } \\
0.006\end{array}$} \\
\hline & & & & \\
\hline Organizational Form & Obs & Median & Mean & Std Error \\
\hline Proprietorship & 1,492 & 0.414 & 0.505 & 0.011 \\
\hline Partnership or LLP & 337 & 0.428 & 0.541 & 0.023 \\
\hline S-Corporation & 1,100 & 0.578 & 0.650 & 0.013 \\
\hline C-Corporation & 1,708 & 0.515 & 0.587 & 0.010 \\
\hline \multicolumn{5}{|l|}{ LLC } \\
\hline Asset Quartile & Obs & Median & Mean & Std Error \\
\hline 1 (Largest) & 1,160 & 0.500 & 0.599 & 0.013 \\
\hline 2 & 1,159 & 0.448 & 0.552 & 0.013 \\
\hline 3 & 1,159 & 0.457 & 0.522 & 0.011 \\
\hline 4 (Smallest) & 1,159 & 0.512 & 0.553 & 0.010 \\
\hline Firm Age & Obs & Median & Mean & Std Error \\
\hline $0-5$ Years & 956 & 0.563 & 0.626 & 0.014 \\
\hline $6-10$ Years & 1,152 & 0.500 & 0.587 & 0.013 \\
\hline $11-20$ Years & 1,433 & 0.460 & 0.538 & 0.011 \\
\hline $21+$ Years & 1,096 & 0.397 & 0.495 & 0.012 \\
\hline Race/Ethnicity & Obs & Median & Mean & Std Error \\
\hline Asian & 308 & 0.453 & 0.542 & 0.024 \\
\hline Black & 442 & 0.471 & 0.559 & 0.020 \\
\hline Hispanic & 291 & 0.434 & 0.535 & 0.025 \\
\hline White & 3,559 & 0.478 & 0.562 & 0.007 \\
\hline Other & 37 & 0.512 & 0.652 & 0.081 \\
\hline Gender & Obs & Median & Mean & Std Error \\
\hline Male & 3,797 & 0.477 & 0.560 & 0.007 \\
\hline Female & 840 & 0.470 & 0.566 & 0.015 \\
\hline
\end{tabular}




\section{Appendix Table A2C \\ Capital Ratios by Selected Firm and Owner Characteristics \\ Data from 1998 SSBF}

Panel A: Capital Structure as Measured by the Ratio of Loans to Assets

\begin{tabular}{|c|c|c|c|c|}
\hline \multirow{2}{*}{\multicolumn{2}{|c|}{$\begin{array}{l}\text { Variable } \\
\text { Loans to Assets }\end{array}$}} & Median & Mean & Std Error \\
\hline & & 0.092 & 0.399 & 0.011 \\
\hline Organizational Form & Obs & Median & Mean & Std Error \\
\hline Proprietorship & 1375 & 0.000 & 0.313 & 0.016 \\
\hline Partnership or LLP & 218 & 0.182 & 0.392 & 0.037 \\
\hline S-Corporation & 1013 & 0.257 & 0.505 & 0.020 \\
\hline C-Corporation & 851 & 0.231 & 0.474 & 0.022 \\
\hline LLC & 28 & 0.538 & 0.576 & 0.113 \\
\hline Asset Quartile & Obs & Median & Mean & Std Error \\
\hline 1 (Largest) & 871 & 0.215 & 0.320 & 0.012 \\
\hline 2 & 870 & 0.184 & 0.361 & 0.016 \\
\hline 3 & 871 & 0.129 & 0.409 & 0.020 \\
\hline 4 (Smallest) & 873 & 0.000 & 0.450 & 0.027 \\
\hline Firm Age & Obs & Median & Mean & Std Error \\
\hline 0 - 5 Years & 890 & 0.087 & 0.473 & 0.023 \\
\hline $6-10$ Years & 707 & 0.161 & 0.425 & 0.023 \\
\hline $11-20$ Years & 1050 & 0.106 & 0.377 & 0.018 \\
\hline $21+$ Years & 838 & 0.022 & 0.301 & 0.019 \\
\hline Race/Ethnicity & Obs & Median & Mean & Std Error \\
\hline Asian & 199 & 0.036 & 0.354 & 0.042 \\
\hline Black & 259 & 0.027 & 0.409 & 0.043 \\
\hline Hispanic & 243 & 0.046 & 0.382 & 0.039 \\
\hline White & 2745 & 0.098 & 0.402 & 0.012 \\
\hline Other & 39 & 0.154 & 0.383 & 0.093 \\
\hline Gender & Obs & Median & Mean & Std Error \\
\hline Male & 2722 & 0.110 & 0.391 & 0.011 \\
\hline Female & 763 & 0.006 & 0.423 & 0.025 \\
\hline
\end{tabular}




\section{Appendix Table A2C \\ Capital Ratios by Selected Firm and Owner Characteristics \\ Data from 1998 SSBF}

Panel B: Capital Structure as Measured by the Ratio of Liabilities to Assets

\begin{tabular}{|c|c|c|c|c|}
\hline \multirow{2}{*}{\multicolumn{2}{|c|}{$\begin{array}{l}\text { Variable } \\
\text { Liabilities to Assets }\end{array}$}} & Median & Mean & Std Error \\
\hline & & 0.347 & 0.756 & 0.019 \\
\hline Organizational Form & Obs & Median & Mean & Std Error \\
\hline Proprietorship & 1375 & 0.111 & 0.635 & 0.031 \\
\hline Partnership or LLP & 218 & 0.400 & 0.722 & 0.070 \\
\hline S-Corporation & 1013 & 0.558 & 0.898 & 0.034 \\
\hline C-Corporation & 851 & 0.536 & 0.886 & 0.039 \\
\hline LLC & 28 & 0.577 & 1.002 & 0.201 \\
\hline Asset Quartile & Obs & Median & Mean & Std Error \\
\hline 1 (Largest) & 871 & 0.436 & 0.544 & 0.017 \\
\hline 2 & 870 & 0.414 & 0.633 & 0.027 \\
\hline 3 & 871 & 0.381 & 0.760 & 0.035 \\
\hline 4 (Smallest) & 873 & 0.025 & 0.940 & 0.051 \\
\hline Firm Age & Obs & Median & Mean & Std Error \\
\hline $0-5$ Years & 890 & 0.421 & 0.916 & 0.043 \\
\hline $6-10$ Years & 707 & 0.411 & 0.834 & 0.043 \\
\hline 11 - 20 Years & 1050 & 0.348 & 0.683 & 0.031 \\
\hline $21+$ Years & 838 & 0.220 & 0.564 & 0.032 \\
\hline Race/Ethnicity & Obs & Median & Mean & Std Error \\
\hline Asian & 199 & 0.213 & 0.610 & 0.071 \\
\hline Black & 259 & 0.185 & 0.765 & 0.076 \\
\hline Hispanic & 243 & 0.271 & 0.670 & 0.066 \\
\hline White & 2745 & 0.362 & 0.768 & 0.021 \\
\hline Other & 39 & 0.387 & 0.799 & 0.187 \\
\hline Gender & Obs & Median & Mean & Std Error \\
\hline Male & 2722 & 0.370 & 0.750 & 0.021 \\
\hline Female & 763 & 0.226 & 0.776 & 0.045 \\
\hline
\end{tabular}




\section{Appendix Table A2D \\ Capital Ratios by Selected Firm and Owner Characteristics \\ Data from 2003 SSBF \\ Panel A: Capital Structure as Measured by the Ratio of Loans to Assets}

$\begin{array}{lrrrr}\text { Variable } & & \text { Median } & \text { Mean } & \text { Std Error } \\ \text { Loans to Assets } & 4163 & 0.074 & 0.614 & 0.025 \\ & & & & \\ \text { Organizational Form } & \text { Obs } & \text { Median } & \text { Mean } & \text { Std Error } \\ \text { Proprietorship } & 1,298 & 0.000 & 0.498 & 0.045 \\ \text { Partnership or LLP } & 337 & 0.141 & 0.548 & 0.063 \\ \text { S-Corporation } & 1,532 & 0.237 & 0.759 & 0.046 \\ \text { C-Corporation } & 941 & 0.261 & 0.719 & 0.050 \\ \text { LLC } & 55 & 0.169 & 0.339 & 0.056 \\ & & & & \\ \text { Asset Quartile } & \text { Obs } & \text { Median } & \text { Mean } & \text { Std Error } \\ \text { 1 (Largest) } & 1,040 & 0.206 & 0.350 & 0.013 \\ 2 & 1,041 & 0.215 & 0.369 & 0.016 \\ 3 & 1,041 & 0.115 & 0.466 & 0.033 \\ 4 \text { (Smallest) } & 1,041 & 0.000 & 0.974 & 0.076 \\ & & & & \\ \text { Firm Age } & \text { Obs } & \text { Median } & \text { Mean } & \text { Std Error } \\ \text { 0 - 5 Years } & 820 & 0.141 & 0.859 & 0.072 \\ \text { 6 - 10 Years } & 797 & 0.128 & 0.585 & 0.050 \\ \text { 11 - 20 Years } & 1,235 & 0.062 & 0.541 & 0.042 \\ \text { 21 + Years } & 1,311 & 0.033 & 0.478 & 0.039 \\ & & & & \\ \text { Race/Ethnicity } & \text { Obs } & \text { Median } & \text { Mean } & \text { Std Error } \\ \text { Asian } & 165 & 0.111 & 0.582 & 0.112 \\ \text { Black } & 119 & 0.000 & 0.775 & 0.176 \\ \text { Hispanic } & 146 & 0.018 & 0.530 & 0.110 \\ \text { White } & 3,616 & 0.074 & 0.591 & 0.026 \\ \text { Other } & 117 & 0.512 & 2.047 & 0.342 \\ & & & & \\ \text { Gender } & \text { Obs } & \text { Median } & \text { Mean } & \text { Std Error } \\ \text { Male } & 3,275 & 0.111 & 0.655 & 0.030 \\ \text { Female } & & 0.000 & 0.496 & 0.046 \\ & & & & \end{array}$




\section{Appendix Table A2D \\ Capital Ratios by Selected Firm and Owner Characteristics \\ Data from 2003 SSBF}

Panel B: Capital Structure as Measured by the Ratio of Liabilities to Assets

\begin{tabular}{|c|c|c|c|c|}
\hline Variable & & Median & Mean & Std Error \\
\hline Liabilities to Assets & 4,163 & 0.275 & 0.849 & 0.030 \\
\hline Organizational Form & Obs & Median & Mean & Std Error \\
\hline Proprietorship & 1,298 & 0.080 & 0.654 & 0.052 \\
\hline Partnership or LLP & 337 & 0.313 & 0.784 & 0.078 \\
\hline S-Corporation & 1,532 & 0.500 & 1.069 & 0.055 \\
\hline C-Corporation & 941 & 0.555 & 1.009 & 0.059 \\
\hline LLC & 55 & 0.459 & 0.771 & 0.171 \\
\hline Asset Quartile & Obs & Median & Mean & Std Error \\
\hline 1 (Largest) & 1,040 & 0.448 & 0.531 & 0.014 \\
\hline 2 & 1,041 & 0.386 & 0.538 & 0.021 \\
\hline 3 & 1,041 & 0.271 & 0.623 & 0.038 \\
\hline 4 (Smallest) & 1,041 & 0.069 & 1.335 & 0.090 \\
\hline Firm Age & Obs & Median & Mean & Std Error \\
\hline $0-5$ Years & 820 & 0.451 & 1.149 & 0.083 \\
\hline $6-10$ Years & 797 & 0.322 & 0.878 & 0.066 \\
\hline $11-20$ Years & 1,235 & 0.260 & 0.733 & 0.048 \\
\hline $21+$ Years & 1,311 & 0.199 & 0.658 & 0.046 \\
\hline Race/Ethnicity & Obs & Median & Mean & Std Error \\
\hline Asian & 165 & 0.386 & 0.831 & 0.128 \\
\hline Black & 119 & 0.240 & 1.113 & 0.234 \\
\hline Hispanic & 146 & 0.229 & 0.769 & 0.127 \\
\hline White & 3,616 & 0.273 & 0.819 & 0.031 \\
\hline Other & 117 & 0.709 & 2.354 & 0.383 \\
\hline Gender & Obs & Median & Mean & Std Error \\
\hline Male & 3,275 & 0.314 & 0.893 & 0.035 \\
\hline Female & 888 & 0.169 & 0.721 & 0.057 \\
\hline
\end{tabular}

